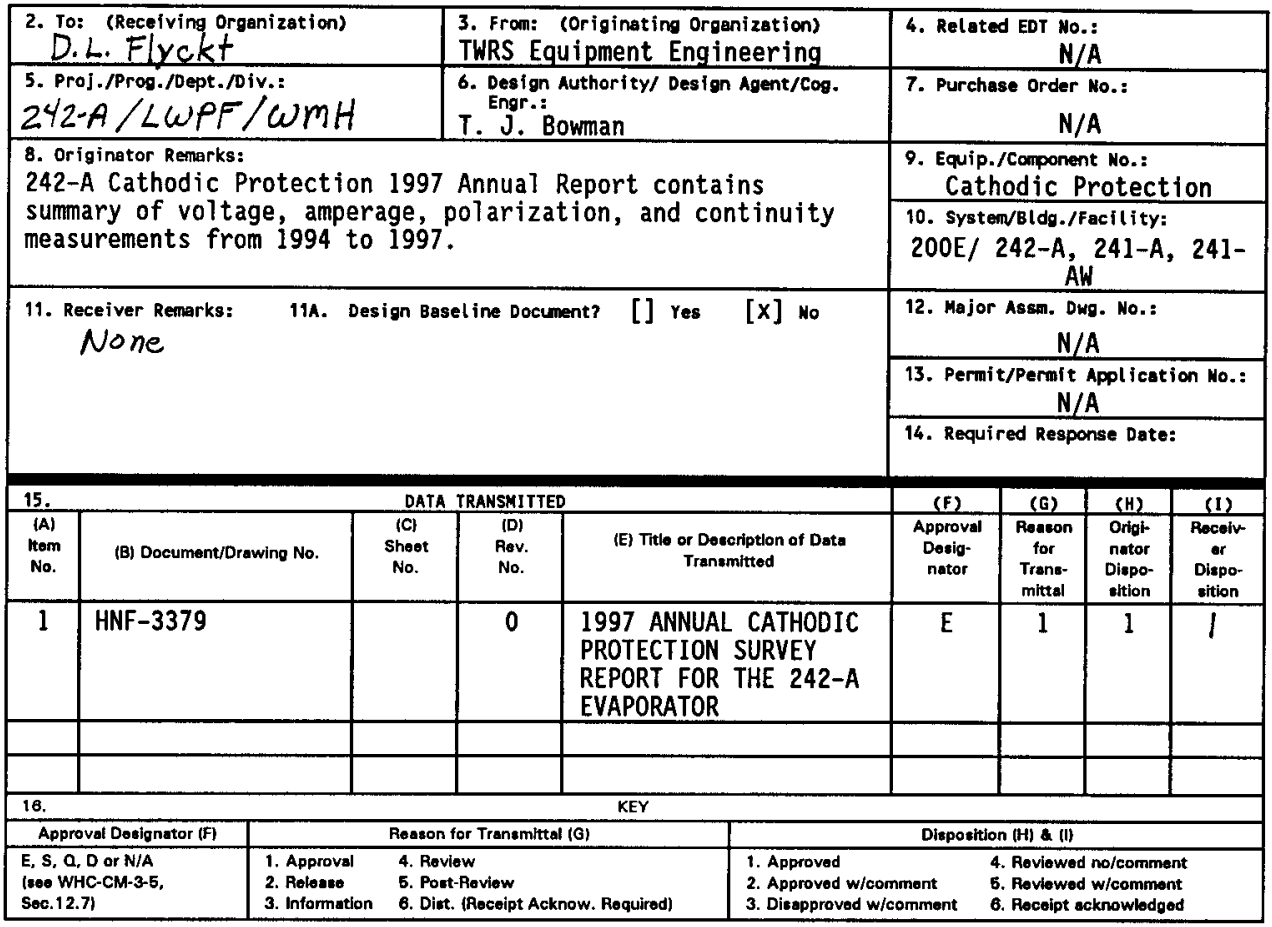

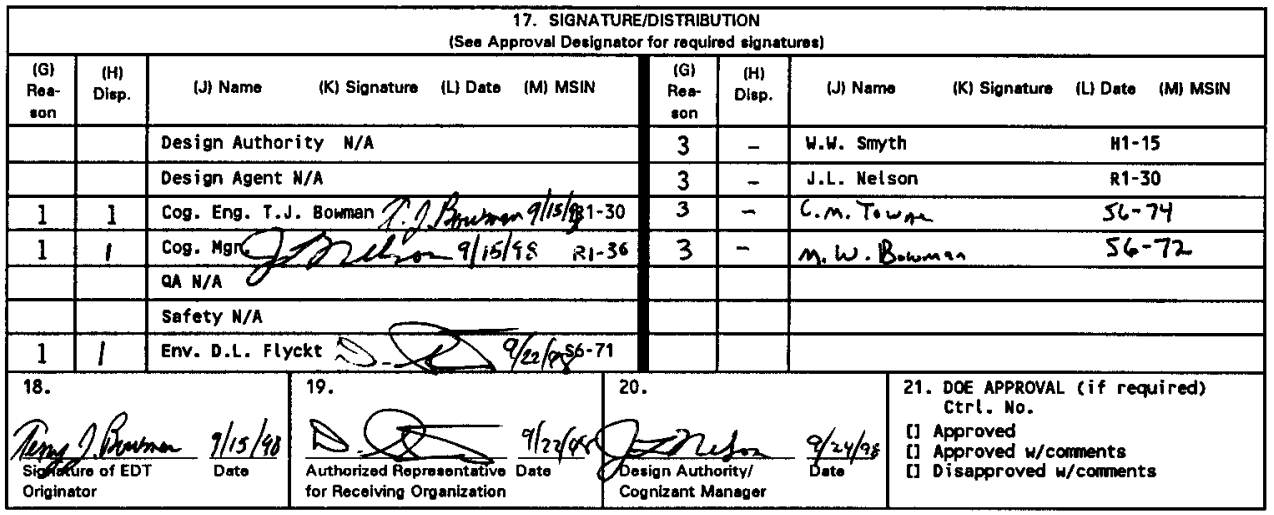

BD -7400-172-2(05/96) GEF097 


\section{Annual Cathodic Protection Survey Report For the 242-A Evaporator}

T. J. Bowman

Lockheed Martin Hanford Corporation, Richland, WA 99352

U.S. Department of Energy Contract DE-ACO6-96RL13200

EDT/ECN: 615265

Org Code: 74711

B\&R Code: EW3130010
UC: 2030

Charge Code: A4021

Total Pages: 49

Key Words: cathodic protection, polarization, rectifiers, protected piping, anodes, continuity

Abstract: This report is the first annual cathodic protection report for the 242-A evaporator. The report documents annual polarization survey data and bimonthly rectifier inspection data from 1994 to 1997.

TRADEMARK DISCLAIMER. Reference herein to any apecific comercisl product, process, or service by trede neme, trademiark, menufacturer, or otherwise, does not necessarily consti tute or imply its endoreament, recommendation, or favoring by the United states Government or any agency thereof or its contractors or subcentractors.

Printed in the United Stetes of America. To obtain copies of this document, contect: Document Control Sarvices, P.O. Box 950, Maitstop M6-08, Richland W4 99352, Phone (509) 372-2420; Fax (509) 376-49\%9.
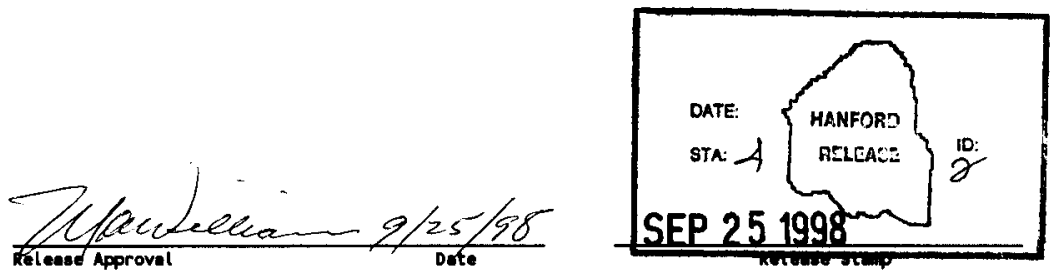

Approved for Public Release 
BNT-3379, REV. 0

1997 MMUNL CATHODIC PROTECTION SURVIT REPORT TOR THE 242-A IVAPORATOR

TABLE OF COWTHWTS

1.0 INTRODUCTION

2.0 LAYOUT OF CATHODIC PROTECTION SYSTEMS AND PIRING SYSTEMS

3.0 DATA COLLECTION

4.0 WASHINGTON STATE CATHODIC PROTECTION REQUIREMENTS

5.0 CATHODIC RROTECTION CRITERIA

6.0 CATHODIC PROTECTION SYSTEM TESTING PROCEDURE

7.0 1997 POLARIZATION SURVEY RESULTS AND ANALYYSIS

8.0 1997 CONTINUITY SURVEY RESULTS AND ANALYSIS

9.0 CONCLUSIONS

10.0 RECOMMENDATIONS

11.0 YEAR 2005 REFURBISHMENTS

12.0 REFERENCES

Page

APPENDIX A Cathodic Protection testing requirements of WAC 173-303-640 and Acceptance Standards of NACE Standard RP0285-95

TABLE 1

Attributes of Rectifier 19 system within AW-Farm property

Attributes of Rectifier 18 system within A-Farm property

Attributes of Rectifier 18 system within Evaporator property

14

TABLE 3

TABLE 4

Attributes of Rectifier R1 system within Evaporator property

Attributes of Evaporator piping

Attributes of A-Farm piping

TABLE 6

TABLE 7

Attributes of AP-Farm piping

TABLE 8

Rectifier Nameplate Data

TABLE 9

Continuity Testing during 1997 annual survey

SPREADSHEET 1

1997 CP Annual Survey Data

GRAPHs (Cathodic Polarization from 1994 to 1997 )

\section{Evaporator Area}

Test station T(33-38)

Test station $\mathrm{T}(33-39)$

Test station $\mathrm{T}(33-40)$

Test Station $\mathrm{T}(33-41)$

Test station 93-T3

Test station 93-T4 
HET-3379, REV. 0

TABLE or CONTENTS (Continued)

GRAPHS (Cathodic Polarization from 1994 to 1997) (Continued)

\section{A-Earm Area}

Test station $T(42-16)$

Test station $\mathrm{T}(42-17)$

Test Station T (42-18)

Test station $\mathrm{T}(42-19)$

Test station $\mathrm{T}(42-21)$

Test Station T (42-38)

Test Station T (42-39)

Test station $\mathrm{T}(\mathbf{4 2 - 4 0 )}$

AW-Farm Area

Test station $\mathrm{T}(33-17)$

Test Station $\mathrm{T}(33-22)$

Test station $T(33-27)$

Test Station $\mathrm{T}(33-34)$

Test station $\mathrm{T}(33-35)$

Test station $\mathrm{T}(33-37)$

GRAPHS (Rectifier DC Outputs during 1994 to 1997 annual surveye)

Rectifier 18 volts and amps

Rectifier 19 volts and amps

GRAPHs (Rectifier Ingpections 1994 to 1997)

Baseline, Resurvey, Bimonthly Inspection Rectifier 18 
HANE -3379 , REV. 0

1997 MNTULI CATHODIC PROTECTION SURVEY RFPORT rOR THE 242-A EVAPORATOR

\subsection{INTRODUCTION}

This cathodic protection (CP) report for the 242-A evaporator area encompasses the following information:

1. 1994 to 1997 CP survey data of voltage and continuity measurements at the test stations of the following areas:

a. 242-A evaporator property;

b. A-Farm property in proximity of the A-Farm valve pits; and

c. AW-Earm property in proximity of the AW-Farm valve pits and in proximity of tanks 241-AW-101 and 241-AW-102;

2. Spreadsheets and tables to tabulate the data, and graphs to trend the data;

3. Bimonthly inspection graph of evaporator Rectifier 18 (EN-RECT-2818) DC voltage and amperage outputs from $7 / 94$ to $7 / 98$;

4. Analysis and recommendations of the 1997 annual $C P$ survey results;

5. Tables listing the attributes of the three rectifier systems associated with the evaporator;

6. Tables listing the attributes of the piping of the evaporator area and associated areas;

7. Table listing continuity measurements at the test stations on evaporator property;

8. Table listing the nameplate output data of the three rectifiers associated with the evaporator;

9. Graphs of three rectifiers DC outputs during the 1994 to 1997 annual surveys; and

10. Appendix documenting applicable Washington Administrative Code (WAC) requirements and National Association of Corrosion Engineers (NACE) standard recommended practices pertaining to CP criteria of corrosion protection.

\subsection{IAYOUT OF CATHODIC PROTECTION SY STIMS AND PIPING SY STEMS}

The CP systems affecting the 242-A evaporator and the piping systems of the evaporator and associated with the 242-A evaporator can be arranged as follows :

1. CR systems and piping physically located on the evaporator property;

2. Evaporator CP system and piping extending within the $A$-farm property, along with A-Farm valve pit piping within A-Farm property; and

3. AW-Farm CP system and the Evaporator and A-farm piping extending within the AW-Farm property.

Complete generalized CP system detail is documented in the 1995 ANNUAL

CATHODIC PROTECTION SURVEY REPORT FOR THE HANEORD 200 AREA.

\section{Evaporator area}

The CP systems operating in the 242-A evaporator property consist of the Reetifier 18 system and the Rectifier R1 (AP241-CATH-RECT-100) system.

Rectifier 18 system is operated and inspected by the evaporator area personnel on the evaporator property and is designed to protect piping on the north and west side of the evaporator. The majority of the west side run of piping in the evaporator property traverses a north-south route between $A-F a r m$ and $A W-$ Farm. Rectifier 18 system extends northward into A-Farm up to the A-Farm valve pits. The southward run of Rectifier 18 system terminates just north of AWFarm buildings.

The attributes of the Rectifier 18 system in the evaporator property are documented in Table 3 .

The attributes of the Evaporator piping are documented in Table 5 . 
HNF-3379, REV, 0

Rectifier RI system is operated by east area personnel but two of its test stations are surveyed by evaporator area personnel on the evaporator property.

The Rectifier RI system protects SN-650 piping between tank 241-AP-102 and the southwest side of the evaporator. SN-650 piping turns north to A-B valve pit and it picks up cathodic protection from Rectifier 18 system. SN-650 piping is bonded into Rectifier 18 system but is not specifically designed for protection by Rectifier 18 system along its north-south route on the west side of the evaporator.

The attributes of the Rectifier $R 1$ system within the evaporator property are documented in Table 4.

The attributes of the AP-Farm SN-650 piping within evaporator property are documented in Table 7 .

\section{Aritrarm area}

The CP system operating in the AW-Farm property consists of the Rectifier 19 (AW241-CATH-RECT-100) system.

Rectifier 19 system is operated and inspected by the east area personnel and the CP system protects the southern run of evaporator piping (Table 5) and the southern run of transfer piping (Table 6) from the A-Farm valve pits.

Rectifier 19 system starts protecting the evaporator area lines and two A-Farm lines at the northern boarder of AW-Farm. The evaporator and AW-Farm lines terminate at the AW-Farm valve pits, the $02 \mathrm{E}$ feed pump pit, and the $02 D$ drain pit.

The attributes of the Rectifier 19 system in protecting the evaporator and AFarm transfer lines are documented in Table 1 .

\section{A-Farm area}

The CP systems operating within the A-Farm property in the proximity of the AFarm valve pits are Rectifiers 15, 16, and 18 systems. Rectifiers 15 and 16 systems add supplementary polarization protection at a few of the Rectifier 18 test stations but offer very limited protection to piping that originates from the evaporator area.

Rectifier 18 system services the A-Farm valve pit area and is operated by the evaporator personnel. Eight test stations of the Rectifier 18 system in AFarm are inspected by east area personnel. Rectifier 18 system extends into A-Farm from the evaporator area and protects piping in proximity of the A-Farm valve pits and protects the evaporator drain lines to the east of the valve pits. The PW-481 evaporator transfer line to A-350 is bonded into Rectifier 18 system but is not specifically designed for protection.

The attributes of the Rectifier 18 system in protecting the evaporator and AFarm transfer lines are documented in Table 2 .

The attributes of the A-Farm piping in proximity to the A-Farm valve pits are documented in Table 6 .

\subsection{DATA COLIECTION}

The collection of annual survey data for this report was accomplished as follows:

1994 and 1995 Test station surveys

Data was collected at the direction of Corrpro companies, Inc.

1996 and 1997 Test station surveys

Data was collected at the direction of TWRS cathodic protection cognizant engineer. Testing was performed per Tank Farm Maintenance Procedures 6-TF-357 Cathodic Protection System Testing, 6-TF-357EE Cathodic Protection System Testing Evaporator (EE), and 6-TE-357ET Cathodic Rrotection System Testing East Tank Farms (ET). 
HANT-3379, REV. 0

The evaporator property 1997 annual survey was performed per work package EL97-00915.

The AW-Farm and A-Farm property 1997 annual surveys were performed per work package 2E-97-2075.

Rectifier 18 Inspection

Rectifier 18 was inspected on a bimonthly basis by the evaporator personnel per Tank Farm Maintenance Procedure, 6-TE-221, Inspection of Cathodic Protection System Rectifiers.

\subsection{WASHINGTON STATE CATHODIC PROTECTION REQUIRMENTS}

WAC 173-303-640 requires corrosion protection of the waste storage and transfer systems. The applicable sections of WAC to cathodic protection inspection are given in Appendix A. Bimonthly rectifier inspections and annual CP surveys are mandated by the state of washington per WAC 173-303-640.

Proper operation of cathodic protection systems is implicitly defined in WAC 173-303-640 by meeting the recommended practices of National Association of Corrosion Engineers (NACE) standard RP0285-95. Pertinent sections of NACE standard RP0285-95 are stated in Appendix A.

\subsection{CATHODIC PROTECTION CRITHRIA}

Corrosion protection is afforded to the outer surface of metallic piping through the application of earthen ionic currents onto the surface of the piping. This method of corrosion mitigation is called cathodic protection. Cathodic protection is used in conjunction with the protective coatings that are applied upon the piping.

The operating criteria to which the Hanford CP systems are evaluated is the NACE Standard Recommended Practice RPO285-95, Item No. 21030, "Corrosion Control of Underground Storage Tank Systems by Cathodic Protection". Either of the three acceptance criteria specified in NACE RPO285-95 can be used as standards at Hanford. The widely accepted criterion of a polarized pipe-tosoil potential of -0.85 volt $D C$, relative to a copper/copper sulfate reference electrode, on buried steel structures is believed to afford practically complete corrosion mitigation to steel and stainless steel in ambient, aerobic, and sulfate-reducing bacteria-free environments. The typical Hanford environment around the piping is believed to fall into the aforementioned category.

The potential measured by specialized instrumentation during the "OFF" cycle of the rectifiers DC output is judged against the polarized (IR-error free) standard of -0.85 millivolts. The 1995 Annual Cathodic Protection survey for the Hanford 200 Area provides a detailed description of the testing equipment.

A second criterion to which cathodic protection is judged protective is described in RPO285-95 as the $100 \mathrm{mV}$ potential shift. A structure is judged to be suitably protected from corrosion if a measurable potential shift of 100 mV or more in the negative direction occurs upon rectifier system energization. The 100 millivolt shift occurs when the instant "OFF" potential as read on the testing equipment is at least $100 \mathrm{mV}$ more negative than the "NATIVE" potential. The NATIVE potential of an underground structure is measured with the rectifier systems not energized. Each 100 millivolts of cathodic polarization gain across a piping surface is believed to reduce the corrosion rate by a factor of 10 . Tests conducted with mild steel coupons placed at five feet in Hanford soil in the 200 West area exhibited corrosion losses of $8 \mathrm{mils}$ in 3.5 years (See reference section). 
HNF-3379, REV, 0

\subsection{CATHODIC PROTECTION BYsTMA TESTING PROCEDURE}

Portable ve Perminent Reference Electrodes

Tank Farm Maintenance Procedure 6-TF-357, Cathodic Protection system Testing, directs the measurement and recording of total potentials and polarized potentials across the underground structures. The voltage measurements are taken with respect to copper/copper sulfate reference electrodes.

Permanent reference electrodes are buried next to the piping being measured. A portable reference electrode is placed upon the ground above the piping being measured. The portable electrode is usually three feet from the closest underground structure while the permanent electrode is designed to be placed within six inches of the piping. The half cell electrodes will give a mean potential over an area of the surface which is a circle whose diameter is approximately four times the structure to half cell electrode distance; the central area will contribute more than the periphery. As a consequence of the distance between piping and electrodes, the portable electrode will measure an integrated potential representing six times the area of the permanent electrode measurement.

The portable electrode cell is measured against other portable electrodes prior to use in the field. The deviation between portable electrodes is usually less than 2 millivolts. With the rectifier turned off, the portable electrode measured against the permanent electrodes should be close to zero. It is impractical to turn off the rectifiers during the annual surveys. It is not known from survey to survey the extent of permanent reference electrode deviation from standards.

The portable reference electrode is considered more accurate than the older deteriorating permanent electrodes. The Rectifier 18, 19, and R1 permanent reference electrodes have been in the ground for over 13 years. However, the placement of the portable reference electrode around the test station varies from survey to survey and the value of the voltage measurements by the portable eleetrodes may vary by as much as 100 millivolts around some at test stations.

Permanent reference electrodes usually measure a more positive pipe-toreference electrode voltage. A high resistance at the electrode to soil interface would cause the voltage values across the piping to measure more positive. The loss of moisture in the soil around the permanent electrode would cause a higher resistance at the electrode-soil interface.

Based on the above discussion, the portable reference electrode measurements are used to judge the $C P$ performance against the acceptance criteria.

Bareline survey

The 7794 survey is called the Baseline survey because this survey represented the first time that polarized potentials across the underground structures were calculated by microprocessor based instrumentation. Prior surveys had measured the negative (cathodic) potential. The negative (cathodic) potential is called the total potential on the test station polarization graphs. The total potential is the potential that would be measured with a multimeter. The negative (cathodic) potential inherently includes voltage drops between the electrode and the piping in addition to the voltage drop across the structure/electrolyte boundary. The IR voltage drops were of unknown magnitude prior to the 1994 Baseline survey.

The microprocessor-based instrumentation has been used in all post $7 / 94$ surveys. Refer to the "1995 Annual Cathodic Rrotection Survey Report for the Hanford 200 Area" for a description of the instrumentation. A description of 
FNT-3379, REV. 0

the cathodic protection systems can be found in the same report.

Continuity effect upon voltage maanurements

Low electrical resistance exists in electrically continuous structures. A stationary reference electrode will measure the same voltage no matter where the connection to electrically continuous structures is made. If the voltage is different between any two structures at a test station it indicates poor or no electrical contact between the structures. Any low voltage readings measured during the survey at a test station indicated a high resistance or isolated structure.

Continuity tests were performed in conjunction with polarization tests to identify those structures and test leads not continuous with the CP systems. These tests were performed by measuring the resistance between one of the test leads from each pipe.

CP Syetem Configuration During Annual survey

Rectifiers 18, 19, R1, 15 , and 16 were all equipped with pulse generators during the annual surveys. The pulse generators allow the "polarized potential" across the piping to be calculated. The pulse generators do not drift and do not have to be synchronized with each other.

Rectifier Rl system was operating with a non-pulsing pulse generator during the 1997 annual survey. The resulting uninterrupted current affected the polarization measurements at two test stations in the evaporator area. However, correlation with 1996 survey readings allowed the polarized potentials to be estimated. The estimated polarized potentials are shown on the graphs of test stations $93-\mathrm{T} 3$ and $93-\mathrm{T} 4$.

\subsection{POLARIZATION SURVEY RESULTS AND ANALYSIS}

\section{Evapoxator Aren Tert stations}

Cathodic polarization across underground piping is measured at six test stations in the evaporator area. Rectifiers 18 and RI systems created the bulk of the polarization values at the six test stations. Rectifier 18 system was running at 19.3 amps (nameplate $=40$ amps) and Rectifier R1 system was running at 20.8 amps (nameplate $=60$ amps) during the 1997 annual survey.

$T(33-38), T(33-39), 93-T 3,93-T 4$

Measurements at four of the six test stations showed that the underground piping was protected above the NACE RP0285-95 4.2.1.2 standard (a negative polarized potential of at least 850 millivolts relative to a saturated copper/copper sulfate electrode). Reference the polarization graphs of test stations $T(33-38), T(33-39), 93-T 3$, and 93-T4. The four-year polarization trends at these test stations shows fairly constant polarization values.

The piping at test stations $T(33-38)$ and $T(33-39)$ receive the majority of their amperage from Rectifier 18 system. The operation of Rectifier 19 system and Rectifier RI system contribute a small amount of polarization across the piping underneath test stations $T(33-38)$ and $T(33-39)$. No effort has been made to isolate Rectifier 19 system or Rectifier R1 system to judge the standalone polarization affect of Rectifier 18 system upon the piping under these two test stations.

$T(33-40), T(33-41)$

Measurements at the other two test stations on the evaporator property gave polarization values of -0.73 and -0.74 volts across the underground piping. Reference the polarization graphs of test stations $T(33-40)$ and $T(33-41)$.

Native potentials of the underground piping have not been measured at the two 
HNT -3379, REV. 0

test stations. The average native potential of the east area is between -0.3 to -0.35 volts. Assuming that the native potential of the underground piping at the two test stations is -0.35 volts, the piping at these two test stations gained at least 380 millivolts of polarization. NACE RP0285-95 4.2.1.3 standard (a minimum of $100 \mathrm{mV}$ of cathodic polarization) would be exceeded by 280 millivolts. The additional 280 millivolts would decrease the corrosion rate at the specific locations by an additional factor of 630 , assuming each 100 millivolts of cathodic polarization gain diminishes corrosion current rate by a decade.

The four-year polarization trend at test station $T(33-40)$ shows a moderate polarization loss, while $T(33-41)$ shows a constant polarization trend.

\section{A-Farm Valve Pit Area Test stations}

Cathodic polarization across underground piping is measured at eight Rectifier 18 test stations in the A-Farm area. Rectifiers 18 system created the bulk of the polarization values across the piping at six of the eight test stations and contributed significantly to the polarization values across the piping at two of the test stations. Rectifier 18 system was running at 19.3 amps (nameplate $=40$ amps) during the 1997 annual survey. Rectifier 15 system and Rectifier 16 system contributed significantly to the polarization values across the piping at five test stations.

$T(42-16), T(42-17), T(42-18), T(42-21), T(42-38), T(42-39), T(42-40)$ Measurements at seven of the eight test stations showed that the underground piping was protected above the NACE RP0285-95 4.2.1.2 standard (a negative polarized potential of at least 850 millivolts relative to a saturated copper/copper sulfate electrode). Reference the polarization graphs of test stations $\mathrm{T}(42-16), \mathrm{T}(42-17), \mathrm{T}(42-18), \mathrm{T}(42-21), \mathrm{T}(42-38), \mathrm{T}(42-39)$, and $\mathrm{T}(42-$ 40). The four-year polarization trends at these test stations shows fairly constant polarization values.

The operation of Rectifier 15 system and Rectifier 16 system contributed significantly to the polarization values across the piping at test stations $T(42-16), T(42-17), T(42-18), T(42-21), T(42-40)$. No effort has been made to isolate Rectifier 15 system or Rectifier 16 system to judge the stand-alone affect of Rectifier 18 system upon the piping under the test stations.

\section{$T(42-19)$}

Cathodic measurements across the piping at one test station gave a polarization value of -0.75 volts. Reference the polarization graph of test station $\mathrm{T}(42-19)$.

A native potential of the piping has not been measured at the test station. At an assumed native potential of -0.35 volts, the piping at the test station would have gained 400 millivolts of polarization. NACE RP0285-95 4.2.1.3 standard (a minimum of $100 \mathrm{mV}$ of cathodic polarization) would be exceeded by 300 millivolts. The additional $300 \mathrm{millivolts}$ would decrease the corrosion rate at the specific location by an additional factor of 1000 , assuming each 100 millivolts of cathodic polarization gain diminishes corrosion current rate by a decade.

The four-year polarization trend at test station $T(42-19)$ shows a moderate polarization loss.

\section{AW-Farm (Valve Pit Area, Tank 101 Area and Tank 102 Area) Test stations} Cathodic polarization is measured across the evaporator and A-Farm piping at six test stations in the AW-Farm area. Rectifiers 19 system created the bulk of the polarization values at the six test stations. Rectifier 19 system was running at 5.5 amps (nameplate = 12 amps) during the 1997 annual survey.

$T(33-37), T(33-35), T(33-34), T(33-27)$

Measurements at four of the six test stations showed that the underground piping was protected above the NACE RP0285-95 4.2.1.2 standard (a negative 
HNY -3379 , REV. 0

polarized potential of at least 850 millivolts relative to a saturated copper/copper sulfate electrode). Reference the polarization graphs of test stations $T(33-37), T(33-35), T(33-34)$, and $T(33-27)$. The four-year polarization trends at these test stations shows fairly constant polarization values.

$T(33-17)$

Measurements at one of the six test station gave a polarization value of -0.70 volts. Reference the polarization graph of test station $T(33-17)$.

A native potential of the piping has not been measured at the test station. At an assumed native potential of -0.35 volts, the piping at the test station would gain 350 millivolts of polarization. NACE RP0285-95 4.2.1.3 standard (a minimum of $100 \mathrm{mV}$ of cathodic polarization) would be exceeded by 250 millivolts. The additional 250 millivolts would decrease the corrosion rate at the specific location by an additional factor of 320 , assuming each 100 millivolts of cathodic polarization gain diminishes corrosion current rate by a decade. The four year polarization trend at test station $T(33-17)$ shows a moderate polarization gain.

\section{T(33-22)}

T(33-22) piping was measured in 1994 at a cathodic polarization value of -.78 volts, a 430 millivolts gain over the average native potential, or a total corrosion rate diminishment by a factor of 20,000 , assuming 100 millivolts diminishes corrosion rate by a decade.

\subsection{CONTINUITY RESULTS AND MNALYSIS}

Test stations are purposefully placed in areas where unprotected piping crosses paths with protected piping. The purpose of placing the test stations above unprotected lines is to allow the continuity testing of the unprotected lines. Conductor leads extend from the unprotected piping up to the test stations. The resistance between the conductors of the protected lines and the conductors of the unprotected lines will show if the unprotected lines are bonded into the $C P$ rectifier system.

The possibility exists that the unprotected lines will pick up CP currents from the nearby $C P$ anodes. If the unprotected piping is not bonded into the $\mathrm{CP}$ rectifier system, then any $\mathrm{CP}$ current picked up by the unprotected piping will have to be discharged to maintain a charge balance. The CP current discharge from piping that is not bonded to the CP rectifier system is in the form of corrosion, i.e., dissolution of the piping. Every pipe at a test station should be bonded into the $C P$ rectifier system.

Continuity measurements were performed in 1997 at all six of the CP test stations located on the evaporator property. The results are tabulated in Table 9 (Continuity Testing during 1997 annual survey).

The piping tested for continuity at each test station is listed in Table 3 (Attributes of Rectifier 18 system within Evaporator Property) and in Table 4 (Attributes of Rectifier R1 system within Evaporator property). Tables 3 and 4 document the piping that is designed to be protected by the CP systems and document the piping that is not designed to be protected by the CP systems.

Northern End of Evaporator Property

The two test stations, i.e., $T(33-40)$ and $T(33-41)$, located at the northern end of Evaporator, showed no resistances over 100 ohms across all the conductors in the test stations. Specific resistances were not recorded.

The polarization testing conducted during the Baseline survey of 7/94 showed the same polarization values against the portable electrode for all ten of the 
structures at $T(33-40)$. The polarization values show that ald ten pipes are bonded into the Rectifier 18 system. Two of the pipes, i.e., DR-338 and DR343, are designed with $C P$ protection and are purposefully bonded to the negative side of Rectifier 18 system.

The polarization testing conducted during the Baseline survey of 7/94 showed the same polarization values against the portable electrode for all nine of the pipes at $T(33-41)$. The polarization values show all nine pipes are bonded into the Rectifiex 18 system. Two of the pipes, i.e., DR-338 and DR-343, are designed with $C P$ protection and are purposefully bonded to the negative side of Rectifier 18 system.

Table 3 documents the bonding of DR-335, DR-334, and DR-343.

\section{Western Find of Evaporator Property}

The two test stations, i.e., $\mathrm{T}(33-38)$ and $\mathrm{T}(33-39)$, located at the western end of Evaporator, showed two pipes that measured over 100 ohms across the protected pipes in the two test stations. At test station T(33-38), pipe 4" SW measured 39 Mohms with respect to pipe SL-167. At test station $T(33-39)$, pipe 14" SW measured 15 Mohms with respect to pipe DR-335.

The polarization testing conducted during the Baseline survey of $7 / 94$ and during the 1997 annual survey showed a lower polarization value for pipe 4" SW when compared against the polarization values of the protected pipes. This indicates no bonding of $4^{\prime \prime}$ SW to the rectifier system.

The polarization testing conducted during the Baseline survey of $7 / 94$ showed a lower polarization value for pipe 14" RW when compared against the polarization values across the protected pipes. Table 3 documents the bonding at $T(33-38)$ and $T(33-39)$. No bonding is shown for the 4" $S W$ or the 14" RW. It is clearly evident that pipe 4" SW and pipe 14" RW are not bonded into the CP Rectifier 18 system.

\section{Interayatem Bonding}

The SN-650 piping running from AP-Farm to the A-B valve pit is bonded to the Rectifier R1 system on the southern end of evaporator. On the path to the A-B valve pit, SN-650 traverses a path through Rectifier 18 system. $5 N-650$ is bonded to the Rectifier 18 system at the A-B valve pit through $S L-113$ and is bonded through pipe 1 ' LA $^{\prime \prime}$ to the Rectifier 18 system as evidenced by the $7 / 94$ baseline polarization values. SN-650 is not designed for protection from Rectifier 18 system but receives protection since it is bonded into the Rectifier 18 system.

The PW481/SN-234 piping from the evaporator to $A-350$ is bonded to the Rectifier 18 system as shown on the As-built drawing that is referenced in Table 3. Test station $T(42-38)$ is available to physically test the bonding of PW-481. PW-481 picks up protective CP current in the evaporator area but does not have any protection along the A-Farm journey to the A-350 catch tank.

Rectifier 19 system is bonded to Rectifier 18 system through DR-343 and SL-167 as shown on $\mathrm{H}-2-91033 \mathrm{Sh} 2$.

Southern End of Evaporator Property

Continuity measurements at test station 93-T3 showed resistances between all the piping to be above 100 ohms. At test station 93-T4, pipe 4" SW measured 3.4 Mohms with respect to pipe SN-650 and pipe 14" RW measure 22 Kohms with respect to $5 \mathrm{~N}-650$.

At 93-T4, the polarization testing conducted during the Baseline survey of $7 / 94$ and during the 1997 and 1996 annual surveys showed lower polarization values for pipe $4^{\prime \prime} \mathrm{SW}$ and pipe 14" RW than the polarization value across the protected pipe. This indicates insufficient or no bonding of the two pipes into the rectifier system. 
HANT-3379, REV. 0

At 93-T3, the polarization testing conducted during the Baseline survey of $7 / 94$ and the resurvey of 1995 showed a significantly lower polarization value for pipe 8" RW and for pipe 4" SW than the polarization value of the protected piping. It is clearly evident that the 4" $\mathrm{SW}$ and the 8" RW are not bonded into the CP system at 93-T3.

At 93-T3 during the 1994 and 1995 surveys, the 3" CT and the 16" M5C piping showed slightly lower polarization values than the polarization value of protected pipe SN-650. These two pipes may not be bonded sufficiently to SN650. The 1997 continuity test at 93-T3 was inconclusive.

\subsection{CONCLUSIONS}

IVaporator Rectifier 18 operation

As of 7/98, the rectifier was running at $15 \%$ of its kilowatt DC output capacity. At this low output, the rectifier is running at 50 \% efficiency.

This efficiency is commonplace for low kilowatt output percentages.

The rectifier is running at $39 \mathrm{DC}$ volts and $19 \mathrm{DC}$ amps, or 1/3 the nameplate voltage of $120 \mathrm{DC}$ volts and $z_{2}$ the nameplate amperage of $40 \mathrm{DC}$ amps. As the underground anodes deteriorate, the system resistance would increase and more voltage would be required for the same amperage. The rectifier has ample voltage left, i.e., 80 volts, to compensate for any future anode deterioration. The Rectifier 18 system was installed in 1985 and no system resistance increase has been shown over the last three years. The rectifier voltage has remained constant at the same tap setting.

\section{Evaporator Rectifier 18 system operation}

All piping originating on the evaporator property, i.e., DR-335, DR-334, DR343, DR-338, SL-168, SN-269, SN-270, SL-113, SL-114, and SL-167, and designed to be protected by the Rectifier 18 system, is protected to the NACE standards implicitly recommended in the WAC. The aforementioned piping is protected within the evaporator area by Rectifier 18 system. DR-335, DR-334, DR-343, SL-114, and SL-113 are also protected within A-Farm by Rectifier 18 system.

All piping originating on the A-Farm property, i.e., SN-220, SN-219, 4001, 4004, SL-100, SL-101, SN-215, SN-216, AND LIQW-702, and designed to be protected by the Rectifier 18 system, is protected to the NACE standards implicitly recommended in the WAC.

\section{AP-Farm Rectifier R1 oystem operation}

Piping SN-650, originating from $A \bar{P}-\bar{F}$ arm, is designed to be protected by the Rectifier RI system on Evaporator property and is protected to the NACE standards implicitly recommended in the WAC.

Afr-Tarm Rectifier 19 system operation All piping originating on the evaporator property or A-Farm property that enters AW-Farm from the evaporator property, i.e., DR-335, DR-334, DR-343, SL-168, SN-269, SN-270, SL-167, SN-220, and SN-219, is protected to the NACE standards implicitly recommended in the WAC. The aforementioned piping is protected within AW-Farm by Rectifier 19 system.

\section{Bonding on Evaporator Property}

All the identified underground piping in the path of the ionic current from the underground anodes of the evaporator property is bonded except for the following piping:

At $T(33-38)-4^{\prime \prime} \mathrm{SW}$ is not bonded;

At $\mathrm{T}(33-39)-14^{\prime \prime} \mathrm{RW}$ is not bonded;

At $93-\mathrm{T} 4-4 " \mathrm{SW}$ is not bonded;

At 93-T3- 4" SW and 8" RW are not bonded; 
HANT -3379, REV. 0

At 93-T3- 3" CT and 16" M5C are bonded but bond is > 100 ohms

\subsection{Recowamidations}

1. Rectifier 18 system on evaporator property

a. Leave tap settings of Rectifier 18 at B-1.

b. Bond $4 " S W, 14 " R W$, and $8 " R W$ at their respective test stations;

c. Conduct resistance test at each test station during annual survey, document values obtained;

d. Conduct efficiency test of rectifier during annual survey.

c. Conduct native potential readings at test stations $T(33-40)$ and $T(33-$ 41).

\subsection{YEAR 2005 REFURBISHMENTS}

Rectifier 18, 19, and R1 systems were installed in 1985. The possibility of system deterioration in the year 2005 would be precipitated by the consumables of the rectifier systems. The consumable items of the rectifier systems are the anodes. The rate of consumption of the anodes in the Hanford complex has never been documented. The collection and analysis of annual survey and bimonthly rectifier inspection data would eventually show the trends of rectifier system performances and the performance relationship to anode integrity.

The anodes are a high silicon, chromium iron, 2 by 60 inch in dimensions with a No. 8 AWG stranded copper lead wire. The anodes were prepackaged in 8 by 96 inch steel canisters with coke breeze backfill.

The weight of the iron in each anode is approximately 25 kilograms 155 pounds).

The iron in the 64 anodes of the Rectifier 18 system originally weighed 1600 kilograms (3520 pounds). If the Rectifier 18 system was running at its present amperage, 20 amps, since 1985, then the rectifier would have delivered 85E09 Faradays of electricity. 85E09 Faradays of electricity would oxide 2430 kilograms (5150 pounds) of iron. If the only reaction at the anode was the oxidation of the iron in the anode structure, then the iron in the anodes of the Rectifier 18 system would have been consumed 4 and years ago. It appears there is another oxidation reaction at the anode. The most likely reaction is the oxidation of water upon the coke breeze backfill. The voltage of the rectifier at the B-1 tap setting, i.e., 39 volts, can easily drive the water oxidation reaction. The aforementioned scenario and analysis does not lead to any specific conclusions concerning the remaining life spans of the Rectifier 18 system anodes.

The anodes would be replaced with the following sequence:

1. Survey the anode locations from the As Built documentation;

2. Determine exact location of anodes with a voltage survey, starting at the locations marked by the As Built determinations;

3. Excavate a hole 12 feet down, removing the original anode material;

4. Splice the lead cable of the new anode to the lead cable from the original anode (the original lead cable is spliced onto the header cables of the Rectifier 18 system;

5. Backfill with soil.

The following assumptions are made in assessing the requirements to refurbish the cathodic protection systems involved with the evaporator complex:

1. Evaporator Rectifier 18 system would require all 64 anodes to be replaced in the evaporator property and the A-Farm property near the valve pit area.

2. AP-Farm Rectifier RI system would require all 5 anodes to be replaced in 
HNT-3379, REV. 0

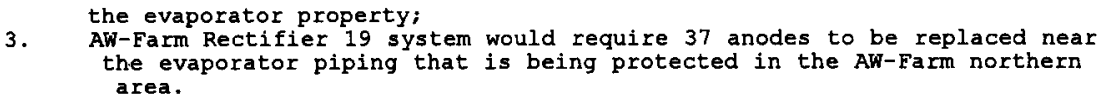

\subsection{RETERTHCRS}

WHC-SD-WM-RPT-266, Rev. 0, 1995 Annual Cathodic Protection Survey Report for the Hanford 200 Area

WHC-SD-WM-TI-230 Rev. 1 - As-Built Design Criteria: B-234 Cathodic Protection, C.P. Wire to Pipe Connections WHC-SD-234-OM-001, REV. 0 - Tank Farm Cathodic Protection System Operation and Maintenance Manual

NACE Standard RP0285-95, Item No. RP02085-95, Standard Recommended Practice, Corrosion Control of Underground Storage Tank Systems by Cathodic Protection H-2-91042 Sh 2 Rev. 3 - Cathodic Protection Plot Plan Test Stations and Jumpers

H-2-91042 Sh 2 Rev. 3 - Cathodic Protection Plot Plan Anode Installation

H-2-91033 Sh 1 Rev. 2 - Cathodic Protection Plot Plan Test Stations and Jumpers

H-2-91033 Sh 2 Rev. 1 - Cathodic Protection Plot Plan Anode Installation H-2-76993 Sh 1 Rev. 1 - Electrical Cathodic Protection Plan \& Det WAC 173-303-640 Tank Systems, Washington State Department of Ecology, Dangerous Waste Regulations, Chapter 173-303 WAC, Publication 92-91 WHC-EP-0891 - Corrosion of Low-Carbon Steel Under Environmental Conditions at Hanford: Two-Year Soil Corrosion Test Results

Cathodic Protection - Theory and Data Interpretation - October 14, 1989, NACE 200 East and West Tank Farms - Cathodic Protection System Survey Report, July 1994

200 Area Tank Farms - Cathodic Protection System Resurvey, March 1995 
HNT -3379, REV. 0

\section{APPERTIX $\mathrm{A}$ \\ Cathodia Protection testing requirements of wAC 173-303-640 and Aoceptance Standarde and uncr standard RP0285-95}

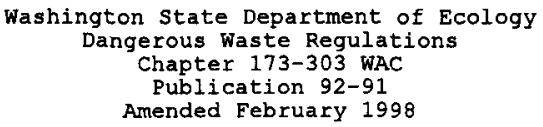

WAC 173-303-640 Tank Systems

p. 95

(1) Applicability

(a) The regulations in WAC 173-303-640 apply to owners and operators of facilities that use tank systems to treat or store dangerous waste, $\ldots$

p. 100

(6) Inspections.

(c) The owner or operator must inspect cathodic protection systems, if present, according to, at a minimum, the following schedule to ensure

that they are functioning properly:

(i) The proper operation of the cathodic protection system must be confirmed within six months after initial installation and annually thereafter; and

(ii) $\ldots$

Note: The practices described in the National Association of Corrosion Engineers (NACE) standard, "Recommended Practice (RP-02-85)Control of External Corrosion on Metallic Buried, Partially Buried, or submerged Liquid storage Systems," and the American Petroleum Institute (API) Publication 1632, "Cathodic Protection of Underground Petroleum storage Tanks and Piping Systems," may be used, where applicable, as guidelines in maintaining and inspecting cathodic protection systems.

(d) $\ldots$

NACE Standard RP0285-95

Item No. 21030

Standar $\frac{1}{d}$ Recommended Practice Corrosion Control of Underground Storage Tank Systems by Cathodic Protection

Note: This standard was originally published in 1985 as "Control of External Corrosion on Metallic Buried, Partially Buried, or Submerged Liquid s-torage Systems."

Section 4: Criteria for Cathodic Protection

\subsection{Criteria for steel structures}

4.2.1 Corrosion control can be achieved at various levels of cathodic polarization depending on the environmental conditions. However, in the absence of data which demonstrate that adequate cathodic protection has been achieved, one of more of the following shall apply: 
GNST-3379, REV. 0

APPENDIX A (continued)

Cathodic Protection testing requirements of WhC 173-303-640 and acoeptance standard of BACE standard RP0285-95

4.2.1.1 A negative (cathodic) potential of at least $850 \mathrm{mV}$ with the cathodic protection applied. This potential is measured with respect to a saturated copper/copper sulfate reference electrode contacting the electrolyte. Voltage drops other than those across the structure/electrolyte boundary must be considered for valid interpretation of this voltage measurement.

4.2.1.2 A negative polarized potential (see definition in Section $1.2)$ of at least $850 \mathrm{mV}$ relative to a saturated copper/copper sulfate reference electrode.

4.2.1.3 A minimum of $100 \mathrm{mV}$ of cathodic polarization. The formation or decay of polarization can be used to satisfy this criterion. 
TABIS: 1

Attributes of Rectifier 19 system within AN-Farm property Reference WHC-SD-WM-TI-230 Rev. 1

\begin{tabular}{|c|c|c|c|c|c|}
\hline Page & Rectifier & $\begin{array}{l}\text { Test } \\
\text { Station }\end{array}$ & Location & $\begin{array}{l}\text { Pipes Designed } \\
\text { For Protection }\end{array}$ & $\begin{array}{l}\text { Pipes Not Designed } \\
\text { For Protection }\end{array}$ \\
\hline 46 & 19 & $\mathrm{~T}(33-17)$ & $\begin{array}{l}\text { Into } \\
241-A W-A\end{array}$ & $\begin{array}{l}\mathrm{SL}-168, \quad \mathrm{SN}-220, \\
\mathrm{SN}-267\end{array}$ & \\
\hline 47 & 19 & $\mathrm{~T}(3 \overline{3}-22)$ & $\begin{array}{l}\text { Into and } \\
\text { near } \\
241-A W-B\end{array}$ & $\begin{array}{l}\text { SL-167, } \\
\text { SN-268-219, }\end{array}$ & $S-100$ \\
\hline 51 & 19 & $\begin{array}{l}\text { T(33-27) } \\
\# 1 \text { \& \#2 }\end{array}$ & $\begin{array}{l}\text { Between } \\
\text { AW-101 } \\
\text { AW-102 }\end{array}$ & $\begin{array}{l}\text { SN-269, } \text { SN } 219, \\
\text { SN-270, } \\
\text { SL-167-220, } \\
\end{array}$ & IA-M7 \\
\hline 57 & 19 & $\mathrm{~T}(33-34)$ & $\begin{array}{l}\text { North of } \\
\text { AW-101 }\end{array}$ & $\begin{array}{l}\text { SN-219, } 5 \mathrm{SN}-220, \\
\mathrm{SL}-168\end{array}$ & DR-371, 1 I" RW, S-100 \\
\hline 57 & 19 & $\mathrm{~T}(33-35)$ & $\begin{array}{l}\text { North of } \\
\text { AW-101 }\end{array}$ & $\begin{array}{l}\mathrm{SN}-269, \mathrm{SN}-270, \\
\mathrm{SL}-167\end{array}$ & \\
\hline $5 \overline{8}$ & 19 & $T(33-37)$ & $\begin{array}{l}\text { North of } \\
\text { Aw-102 }\end{array}$ & $\begin{array}{l}\text { DR-335, DR-334, } \\
D R-343\end{array}$ & \\
\hline
\end{tabular}

TABLF 2

Attributes of Rectifier 18 gyetem within A-Iarm property Reference WHC-SD-WM-TI-230 Rev. 1

\begin{tabular}{|c|c|c|c|c|c|}
\hline Page & Rectifier & $\begin{array}{l}\text { Test } \\
\text { station }\end{array}$ & Location & $\begin{array}{l}\text { Pipes Designed } \\
\text { For Protection }\end{array}$ & $\begin{array}{l}\text { Pipes Not Designed } \\
\text { For Protection }\end{array}$ \\
\hline 67 & 18 & $T(42-16)$ & $\begin{array}{ll}\text { South of } \\
\text { A } & \text { valve } \\
\text { pits } & \end{array}$ & $\mathrm{SN}-219, \quad \mathrm{SN}-220$ & \\
\hline 67 & 18 & $\mathrm{~T}(42-17)$ & $\begin{array}{l}\text { South of } A \\
\text { Valve pits }\end{array}$ & $\begin{array}{l}\mathrm{SN}-215, \quad \mathrm{SN}-216, \\
\mathrm{SL}-114, \mathrm{SL}-113\end{array}$ & $\begin{array}{l}\text { DR-301, Bundle of } \\
3_{2} \text { " purge lines }\end{array}$ \\
\hline $6 \overline{8}$ & 18 & $T(42-18)$ & $\begin{array}{l}\text { Into } \\
\text { Near } A-A \\
\text { valve pit }\end{array}$ & $\begin{array}{l}\text { LIQW-702, 4001, } \\
4004\end{array}$ & SN-207, SL-107 \\
\hline $6 \overline{8}$ & 18 & $T(42-19)$ & $\begin{array}{l}\text { Into } \\
\text { near } A-A \\
\text { valve pit }\end{array}$ & $\begin{array}{l}\text { LIQW-702, } 4001 \text {, } \\
4004, \text { SL-101 }\end{array}$ & $\mathrm{EL}, \quad \mathrm{SN}-207$ \\
\hline 69 & 18 & $T(42-20)$ & $\begin{array}{l}\text { North of } A \\
\text { valve pits }\end{array}$ & SL-100, SL-101 & $\begin{array}{ll}\text { SN-213, } & \text { SN-214, } \\
\text { two } & \text { 1/" } \\
\text { lines, } 4107 & \text { purge }\end{array}$ \\
\hline 69 & 18 & $T(42-21)$ & $\begin{array}{l}\text { North of } A \\
\text { valve pits }\end{array}$ & SL-100, SL-101 & 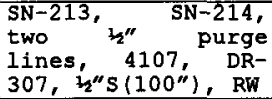 \\
\hline 69 & 18 & $T(42-40)$ & $\begin{array}{l}\text { North of } A \\
\text { valve pits }\end{array}$ & SL-100, SL-101 & $\begin{array}{lr}\text { SN-213, } & \text { SN-214, } \\
\text { two } & \text { purn } \\
\text { lines, VENT } & \end{array}$ \\
\hline $7 \overline{0}$ & 18 & $T(42-38)$ & $\begin{array}{l}\text { North } \\
242-A\end{array}$ & $\begin{array}{l}\text { DR-343, } \\
\text { DR-335 }\end{array}$ & $\mathrm{SN}-235, \mathrm{PW}-481$ \\
\hline 70 & 18 & $T(42-39)$ & $\begin{array}{l}\text { Noxth } \\
242-A\end{array}$ & $\begin{array}{l}\text { DR-343, } \overline{D R}-334, \\
D R-335\end{array}$ & $\begin{array}{l}\text { Abandoned } \\
\text { plugged and } \\
\text { DR-334, DR-335 }\end{array}$ \\
\hline
\end{tabular}


HNY -3379, REV. O

TABLE 3

Attributes of Rectifier 18 system within Ivaporator property Reference WHC-SD-WM-TI-230 Rev. 1

\begin{tabular}{|c|c|c|c|c|c|}
\hline Page & Rectifier & $\begin{array}{l}\text { Test } \\
\text { station }\end{array}$ & Location & $\begin{array}{l}\text { Pipes Designed } \\
\text { For Protection }\end{array}$ & $\begin{array}{l}\text { Pipes Not Designed } \\
\text { For Protection }\end{array}$ \\
\hline 59 & 18 & $T(33-38)$ & $\begin{array}{l}\text { Between } \\
242-A \text { and } \\
A W-\text { farm }\end{array}$ & $\begin{array}{ll}S N-269, & S N-270, \\
\text { SL-167, } & \text { SN-219 }\end{array}$ & $4^{\prime \prime} S W$ \\
\hline & & $\begin{array}{l}\text { BONDING } \\
\text { at } \mathrm{T}(33- \\
38) \text { and } \\
\mathrm{T}(33-39)\end{array}$ & & $\begin{array}{ll}\text { DR-335, } & \text { SN-269, } \\
\text { SN-270, } & \text { DR-334, } \\
\text { SL-167, } & \text { DR-343, } \\
\text { SN-219, } & \text { SN-220, } \\
\text { SL-168 } & \end{array}$ & \\
\hline 59 & 18 & $T(33-39)$ & $\begin{array}{l}\text { Between } \\
242-A \text { and } \\
A W-\text { Earm }\end{array}$ & $\begin{array}{ll}\text { DR-335, } & \text { DR-334, } \\
\text { DR-343, } & \text { SN-220, } \\
S L-168 & \end{array}$ & $14^{\prime \prime} \mathrm{RW}$ \\
\hline 60 & 18 & $\begin{array}{l}T(33-40) \\
\# 1 \& \# 2\end{array}$ & $\begin{array}{l}\text { North } \\
\text { side of } \\
242-A\end{array}$ & $\mathrm{DR}-338, \mathrm{DR}-343$ & $\begin{array}{l}\text { DRAIN, SC-501, AS- } \\
1705, \text { IA-704, DR- } \\
\text { M42, airline, cond } \\
\text { drain, CMP }\end{array}$ \\
\hline 60 & 18 & $\begin{array}{l}T(33-41) \\
\# 1 \& \# 2\end{array}$ & $\begin{array}{l}\text { North } \\
\text { side of } \\
242-\mathrm{A}\end{array}$ & $\mathrm{DR}-343, \mathrm{DR}-338$ & $\begin{array}{l}\text { PC-557, } 8 \text { DUCT, } \\
30^{\prime \prime} \text { DUCT, As-1705, } \\
\text { IA-704, } \\
\text { DR-341 airline, }\end{array}$ \\
\hline 71 & 18 & BONDING & $\begin{array}{l}\text { West side } \\
\text { of } 242-A\end{array}$ & $\begin{array}{l}\text { SN-269, } \\
\text { SL-167, } 270, \\
\text { SL-113, } \\
\text { SL-168, }\end{array}$ & $\begin{array}{l}\mathrm{PW}-481, \quad \mathrm{BN}-235, \quad 1 \\
y_{2}^{\prime \prime} \mathrm{PA}\end{array}$ \\
\hline 73 & 18 & BONDING & $\begin{array}{l}\text { Between } \\
242-A \text { and } \\
\text { A valve } \\
\text { pit }\end{array}$ & $\begin{array}{ll}\text { DR-335, } & \text { SL-114, } \\
\text { SL-113, } & \text { DR-343, } \\
\text { DR-334 } & \end{array}$ & $\begin{array}{l}\mathrm{PW}-481, \mathrm{SN}-235, \mathrm{DR}- \\
301\end{array}$ \\
\hline
\end{tabular}

\section{TABLE 4}

Attribute: of Rectifier $\mathbf{R 1}$ aystom within Evaporator property Reference $\mathrm{H}-2-76933$ Sh 1 and $7 / 94$ CP testing

\begin{tabular}{|c|c|c|c|c|c|}
\hline Page & Rectifier & $\begin{array}{l}\text { Test } \\
\text { Station }\end{array}$ & Location & $\begin{array}{l}\text { Pipes Designed } \\
\text { For Protection }\end{array}$ & $\begin{array}{l}\text { Pipes Not Designed } \\
\text { For Protection }\end{array}$ \\
\hline & R1 & 93-พ3 & $\begin{array}{l}\text { South of } \\
242-A\end{array}$ & SN-650 & $\begin{array}{l}8^{\prime \prime} \text { RW, } 4^{\prime \prime} \text { SW, } 16^{\prime \prime} \\
\text { M5C, CT }\end{array}$ \\
\hline & R1 & $93-14$ & $\begin{array}{l}\text { South of } \\
242-\mathrm{A}\end{array}$ & $\mathrm{SN}-650$ & $\begin{array}{l}14^{\prime \prime} \mathrm{RW}, 4^{\prime \prime} \mathrm{SW}, 1 \text { L } \\
\mathrm{PA}-\mathrm{M} 7\end{array}$ \\
\hline
\end{tabular}




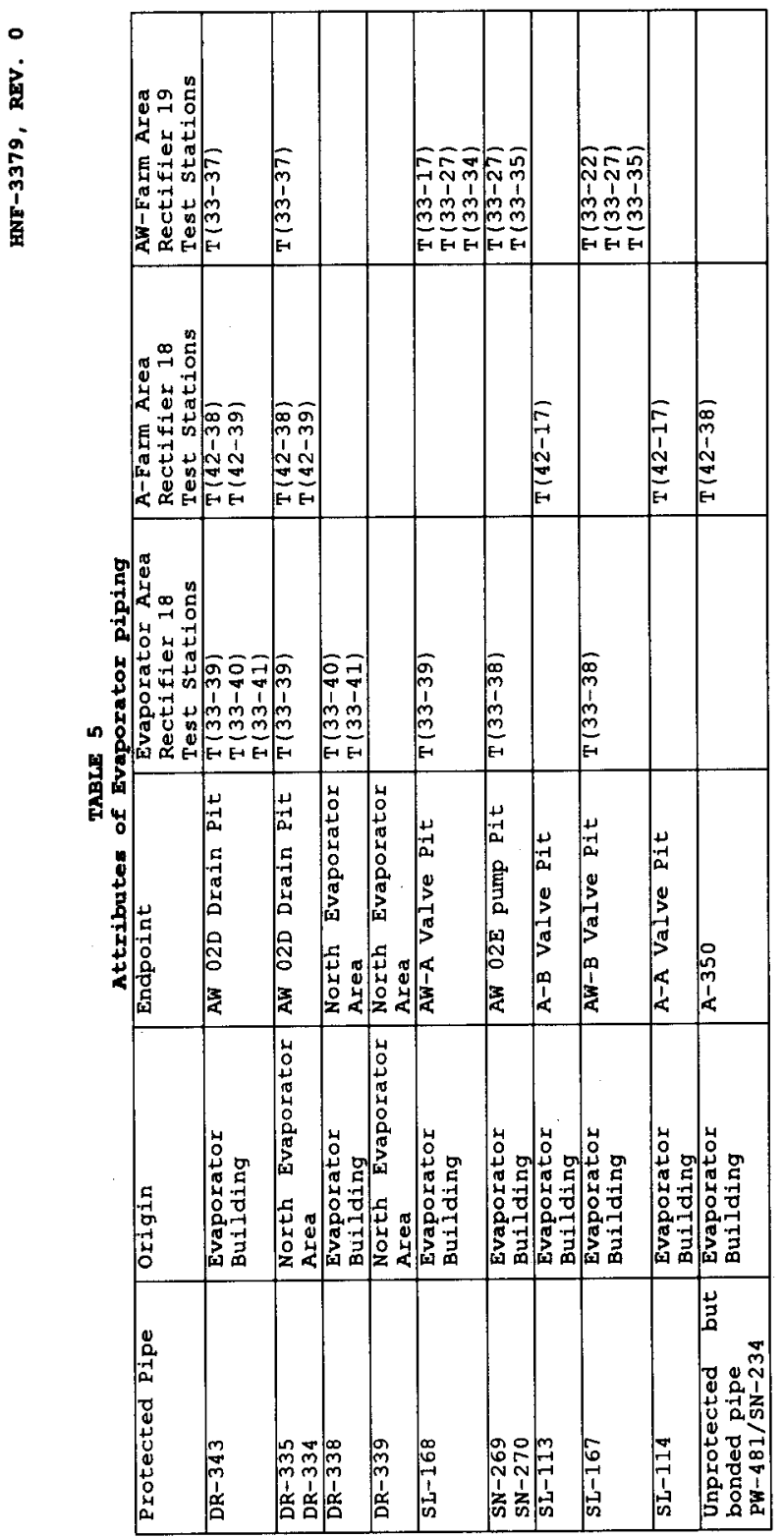




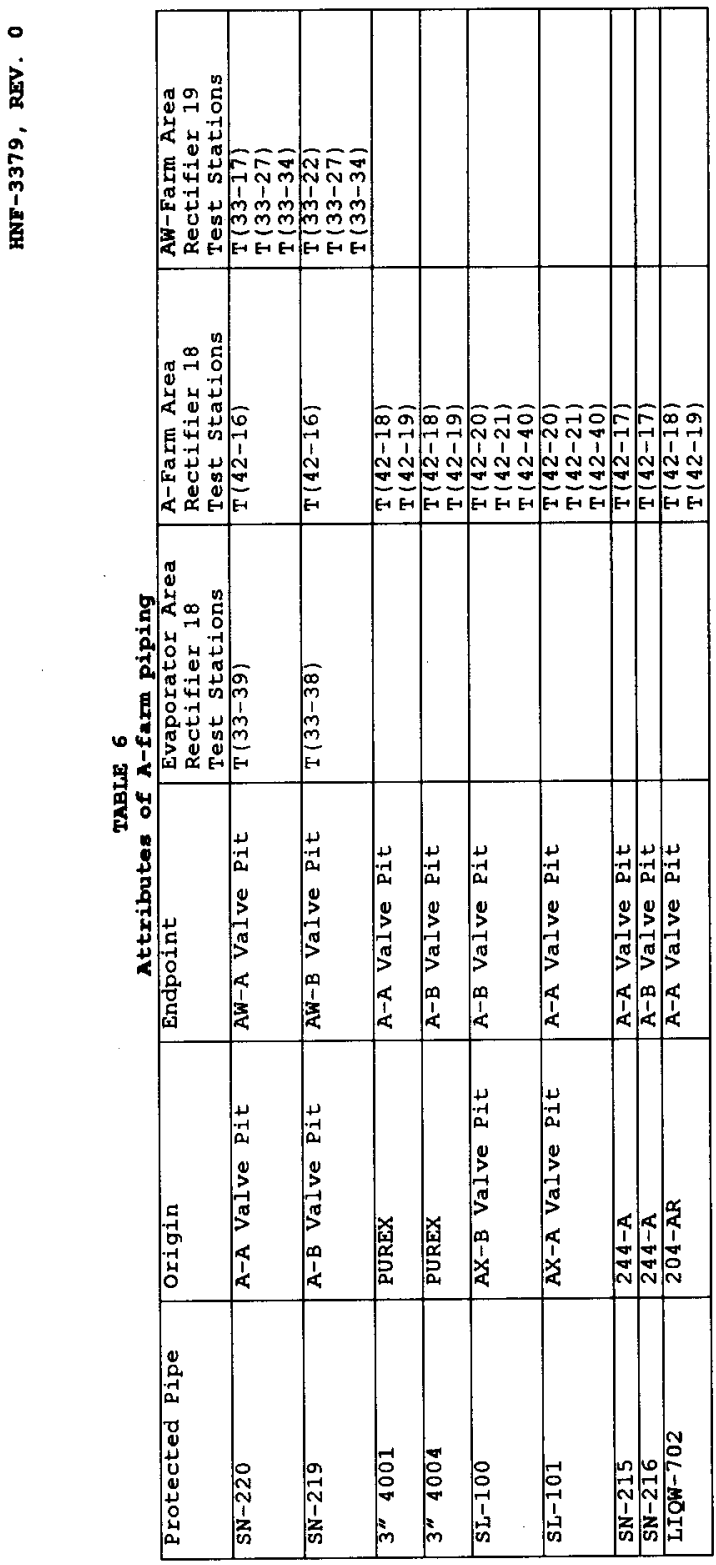


HNT-3379, REV. O

TABIE: 7

Attributes of AP-Farm piping

\begin{tabular}{|l|l|l|l|}
\hline Protected Pipe & Origin & Endpoint & $\begin{array}{l}\text { Evaporator Area } \\
\text { Rectifier R1 } \\
\text { Test Stations }\end{array}$ \\
\hline SN-650 & A-B Valve Pit & $102-A P$ & $\begin{array}{l}93-T 3 \\
93-T 4\end{array}$ \\
\hline
\end{tabular}

TABIS 8

Rectifier Namoplate Data

\begin{tabular}{|l|l|l|}
\hline Rectifier & Nameplate DC voltage rating & Nameplate DC amperage rating \\
\hline 18 & 120 & 40 \\
\hline 19 & 40 & 12 \\
\hline RI & 100 & 60 \\
\hline
\end{tabular}

TABLE 9

Continuity Testing during 1997 annual survey

\begin{tabular}{|c|c|c|}
\hline Test station & Specified Test Conductor & $\begin{array}{l}\text { Conductor resistance to } \\
\text { specified Test conductor, } \\
\text { ohms }\end{array}$ \\
\hline$T(33-41) \# 1$ & AS-1705 & None over 100 ohms \\
\hline $\mathrm{T}(33-41) \# 2$ & $30^{\prime \prime}$ Duct & None over 100 ohms \\
\hline $\mathrm{T}(33-40) \# 1$ & $I_{2 \prime \prime}^{\prime \prime}$ IA 704 & None over 100 ohms \\
\hline $\mathrm{T}(33-40) \# 2$ & $24^{\prime \prime} \mathrm{CMP}$ & None over 100 ohms \\
\hline $\mathrm{T}(33-38)$ & $5 L_{-167}$ (protected pipe) & $4^{\prime \prime} S W-39$ Mohms to SL-167 \\
\hline $\mathrm{T}(33-39)$ & DR-335 (protected pipe) & $14^{\prime \prime}$ RW - 15 Mohms to DR-335 \\
\hline $93-\mathrm{T} 4$ & SN-650 (protected pipe) & $\begin{array}{lll}14^{\prime \prime} \mathrm{RW}-22 & \text { Kohms to } \mathrm{SN}-650 \\
4^{\prime \prime} \mathrm{SW}-3.4 & \text { Mohms to } \mathrm{SN}-650\end{array}$ \\
\hline $93-\mathrm{T}^{3}$ & $\begin{array}{l}3^{\prime \prime} \text { CT (bonded to protected } \\
\text { pipe, shown by } 1 / 95 \& 7 / 94 \\
\text { voltage testing) }\end{array}$ & $\begin{array}{l}\text { Every pipe in test station - } \\
\text { over } 100 \text { ohms to } 3^{\prime \prime} \mathrm{CT}\end{array}$ \\
\hline
\end{tabular}




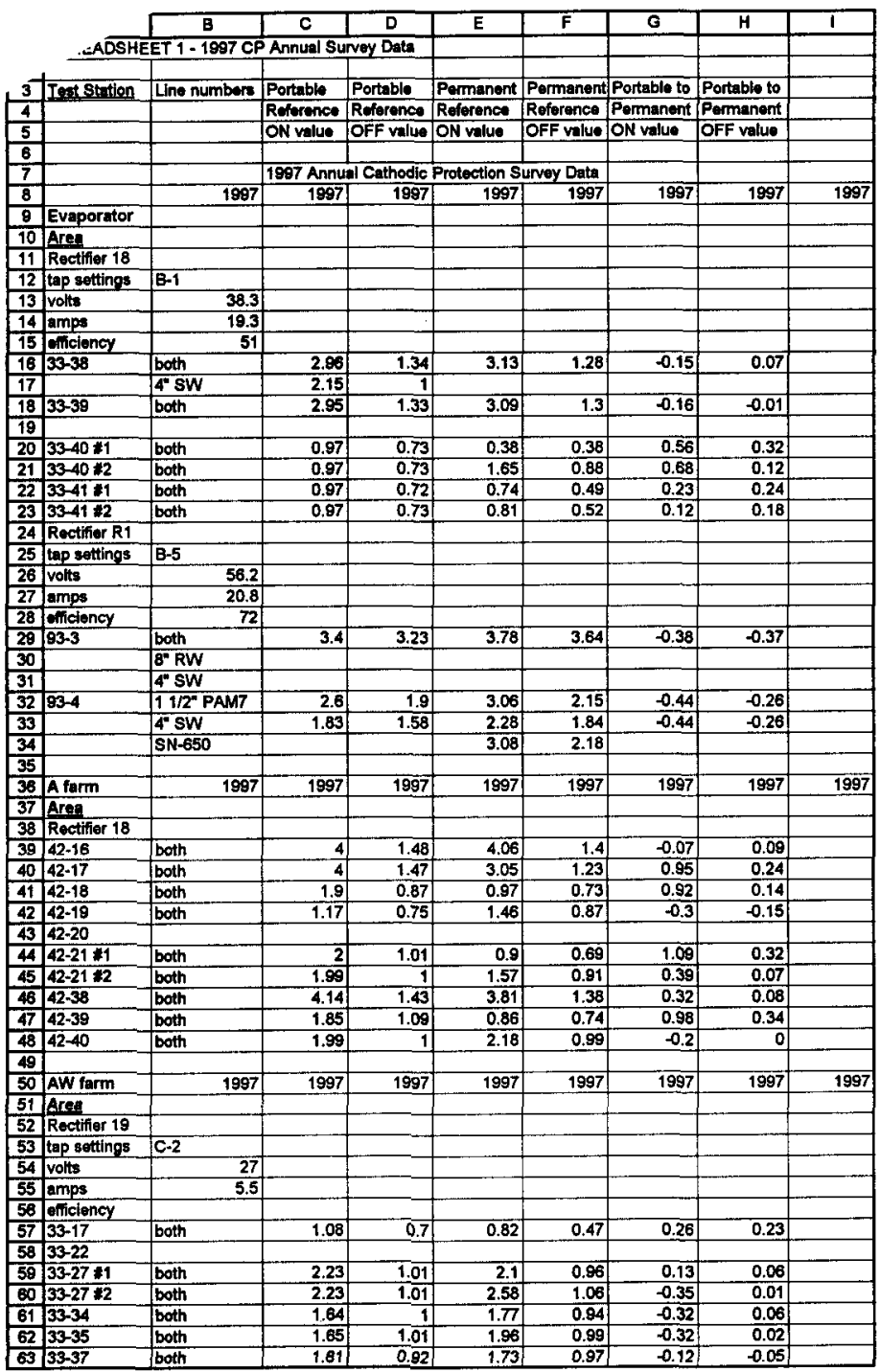




\begin{tabular}{|c|c|c|c|c|c|c|c|c|c|c|c|c|}
\hline & $\mathbf{A}$ & $\mathbf{B}$ & $\mathrm{C}$ & D & $\bar{E}$ & $F$ & $\mathbf{G}$ & $\mathbf{H}$ & 1 & $\mathrm{~J}$ & $\bar{K}$ & $\mathbf{L}$ \\
\hline 1 & SPREADSH & ET 2 - $1996 \mathrm{CP}$ & Annual Sun & ivey Data & & & & & & & & \\
\hline \multicolumn{13}{|c|}{ 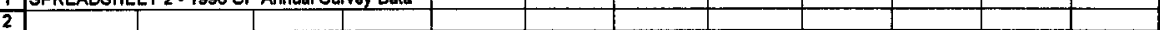 } \\
\hline 3 & Iest Station & Line numbers & Portable & Portnble & Permanent & Permanent & Portable to & Portable to & & & & \\
\hline 4 & & & Reference & Reference & Reference & Reference & Permanent & Permanent & & & & \\
\hline 5 & & & ON value & OFF value & ON value & OfF value & ON value & OFF value & & & & \\
\hline \multicolumn{13}{|l|}{6} \\
\hline 7 & & & \multicolumn{4}{|c|}{1993 Annugal Cathodic Protection Survey Data } & & & & & & \\
\hline 8 & & 1996 & 1996 & 1996 & 1996 & 1998 & 1996 & 1996 & 1996 & 1996 & 1996 & 1996 \\
\hline 9 & Evaporator & & & & & & & & & & & \\
\hline 10 & Ars? & & & & & & & & & & & \\
\hline 11 & Rectifier 18 & & & & & & & & & & & \\
\hline 12 & tap rottings & B-1 & & & & & & & & & & \\
\hline 13 & volts & 38.4 & & & & & & & & & & \\
\hline 14 & amps & 25.5 & & & & & & & & & & \\
\hline 15 & efticlency & & & & & & & & & & & \\
\hline 16 & $33-38$ & both & 2.76 & 1.26 & 3.23 & 1.3 & -0.47 & -0.08 & & & & \\
\hline 17 & & & & & & & & & & & & \\
\hline 18 & $33-39$ & both & 2.76 & 1.25 & 2.35 & 1.2 & 0.41 & 0.04 & & & & \\
\hline 19 & & & & & & & & & & & & \\
\hline 20 & $33-40 \leqslant 1$ & both & 2.14 & 1.05 & 0.56 & 0.46 & 1.6 & 0.8 & & & & \\
\hline 21 & $33-40 \div 2$ & & 2.14 & 1.05 & 2.27 & 1.03 & -0.14 & 0.03 & & & & \\
\hline 22 & $33-4151$ & cant find & & & & & & & & & & \\
\hline 23 & $33-41 \div 2$ & can't find & & & & & & & & & & \\
\hline 24 & Rectifier R1 & & & & & & & & & & & \\
\hline 25 & tap sottings & $B-5$ & & & & & & & & & & \\
\hline 28 & volls & 55 & & & & & & & & & & \\
\hline 27 & amps & 33.9 & & & & & & & & & & \\
\hline 28 & eficiency & & & & & & & & & & & \\
\hline 29 & $93-3$ & both & 3.5 & 1.27 & 3 & 1.35 & 0.5 & -0.09 & & & & \\
\hline 30 & & $g^{\prime \prime} R W$ & & & & & & & & & & \\
\hline 31 & & 4" SW & & & & & & & & & & \\
\hline 32 & $93-4$ & $11 / 2^{n}$ PAM7 & 3 & 1.16 & 3.07 & 1.07 & -0.12 & 0.06 & & & & \\
\hline 33 & & 4 sW & 1.92 & 0.83 & 2.04 & 0.76 & -0.12 & 0.06 & & & & \\
\hline 34 & & $8 N-650$ & & & & & & & & & & \\
\hline 35 & & & cals PAM7 & & & & & & & & & \\
\hline 38 & A farm & 1998 & 1996 & 1996 & 1996 & 1996 & 1996 & 1996 & 1996 & 1996 & 1996 & 1996 \\
\hline 37 & Ares: & & & & & & & & & & & \\
\hline 38 & Rectifier 18 & & & & & & & & & & & \\
\hline 39 & $42-18$ & both & 4.24 & 1.97 & 4.09 & 1.76 & 0.81 & 0.29 & & & & \\
\hline 40 & $42-17$ & both & 4 & 1.97 & 3.25 & $\$ .27$ & 2.84 & 0.46 & & & & \\
\hline 41 & $42-18$ & tent cover & & & & & & & & & & \\
\hline 42 & $42-19$ & both & 1.81 & 0.94 & 1.1 & 0.79 & 0.71 & 0.16 & 2.39 & 0.99 & -0.58 & -0.09 \\
\hline$\frac{7}{43}$ & $42-20$ & & & & & & & & & & & \\
\hline 44 & $42-21 \geqslant 1$ & both & 1.8 & 0.98 & 0.99 & 0.76 & 0.81 & 0.22 & & & & \\
\hline 45 & $42-21 * 2$ & both & 1.8 & 0.98 & 1.67 & 0.97 & 0.13 & 0.01 & & & & \\
\hline$\frac{\pi}{46}$ & $42-38$ & both & 4.28 & 1.6 & 4.33 & 1.49 & 0.73 & 0.05 & & & & \\
\hline 47 & $42-39$ & both & 2.8 & 1.28 & 0.92 & 0.78 & 1.89 & 0.49 & & & & \\
\hline 48 & $42-40$ & both & 2.13 & 1.03 & 2.11 & 1 & -0.06 & 0.02 & & & & \\
\hline 49 & & & & & & & & & & & & \\
\hline 50 & AW farm & 1996 & 1996 & 1996 & 1996 & 1996 & 1996 & 1996 & 1996 & 1996 & 1996 & 1996 \\
\hline 51 & Are? & & & & & & & & & & & \\
\hline 52 & Rectlfier 19 & & & & & & & & & & & \\
\hline 53 & tap settings & C-2 & & & & & & & & & & \\
\hline 54 & volts & 26.5 & & & & & & & & & & \\
\hline 5 & amps & 9.4 & & & & & & & & & & \\
\hline 56 & eficiency & & & & & & & & & & & \\
\hline 57 & $33-17$ & uder raceway & & & & & & & & & & \\
\hline 58 & $33-22$ & & & & & & & & & & & \\
\hline 59 & $33-27 \# 1$ & both & 2.47 & 1.09 & 2.18 & 0.99 & 0.28 & 0.11 & & & & \\
\hline 60 & $33-27$ & both & 2.46 & 1.09 & 2.77 & 1.08 & -0.31 & 0.04 & & & & \\
\hline 81 & $33-34$ & both & 4.78 & 1.01 & 1.19 & 0.71 & 0.58 & 0.31 & & & & \\
\hline 62 & $33-35$ & both & 1.78 & 1.01 & 1.99 & 1.04 & -0.21 & -0.03 & & & & \\
\hline 63 & $33-37$ & both & 2.22 & 1.18 & 1.95 & 1.04 & 0.27 & 0.15 & & & & \\
\hline
\end{tabular}




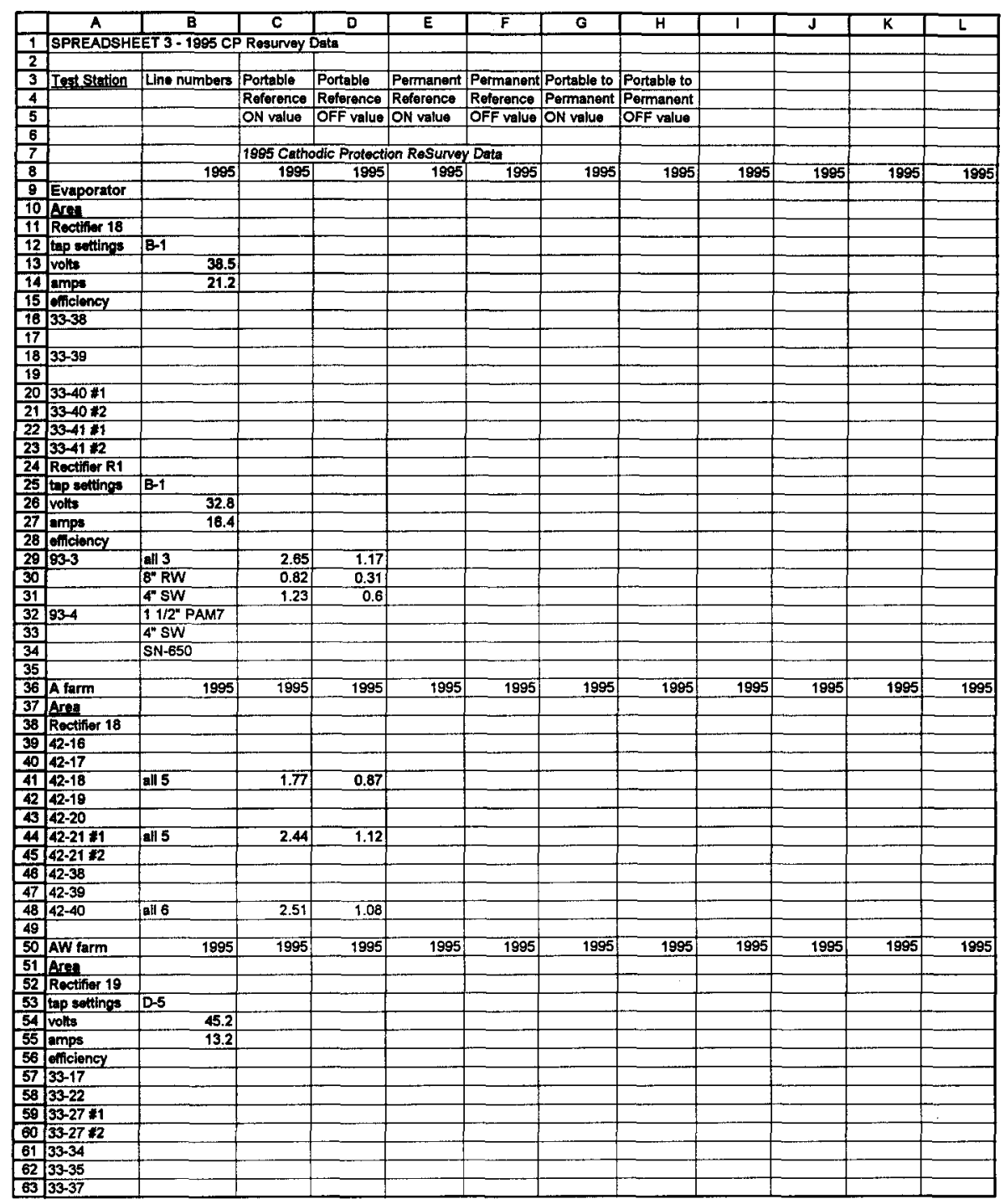




\begin{tabular}{|c|c|c|c|c|c|c|c|c|c|c|c|c|}
\hline & A & $\mathbf{B}$ & C & D & $E$ & $F$ & $\mathbf{G}$ & $\mathbf{H}$ & 1 & $J$ & $\mathbf{K}$ & $\mathrm{L}$ \\
\hline 1 & SPREADSH & ET 4-1094 CF & Baseline Su & Survey Data & & & & & & & & \\
\hline \multicolumn{13}{|l|}{$\overline{2}$} \\
\hline 3 & Intstention & Line numbers & Portbile & Portable & Permanent & Permanent & Portable to & Portable to & & & & \\
\hline 4 & & & Reference & Reforence & Referenco & Roference & Permanent & Permanent & & & & \\
\hline 5 & & & ON value & OFF value & ON value & OFF value & ON value & OFF value & & & & \\
\hline \multicolumn{13}{|l|}{6} \\
\hline 7 & & & \multicolumn{5}{|c|}{ 1994 Baseline Cathodic Protection Survey Data } & & & & & \\
\hline 8 & & 1994 & 1994 & 1994 & 1994 & 1994 & 1994 & 1994 & 1994 & 1994 & 1994 & 1994 \\
\hline 9 & Evaporator & & & & & & & & & & & \\
\hline 10 & Are? & & & & & & & & & & & \\
\hline 11 & Rectfilier 18 & & & & & & & & & & & \\
\hline 12 & tap seltings & $B-2$ & & & & & & & & & & \\
\hline 13 & volts & 44 & & & & & & & & & & \\
\hline 14 & amps & 32.9 & & & & & & & & & & \\
\hline 15 & enilieiency & & & & & & & & & & & \\
\hline 16 & $33-38$ & all 4 & 4.41 & 1.37 & 4.05 & 1.23 & 0.56 & & 2.89 & 1.3 & 1.64 & \\
\hline 17 & & $4^{*} \mathrm{SW}$ & 2.91 & 0.94 & 2.19 & 0.79 & 0.56 & & 1.2 & 0.76 & 1.84 & \\
\hline 18 & 33-39 & Dr 334 & 4.4 & 1.37 & 4.1 & 1.26 & 0.38 & & 3.29 & 1.27 & 1.33 & \\
\hline 19 & & $14^{\prime \prime} \mathrm{RW}$ & 2.92 & 0.97 & 2.46 & 0.87 & 0.38 & & 1.6 & 0.81 & 1.33 & \\
\hline 20 & $33-40 * 1$ & all 4 & 1.33 & 0.78 & 0.63 & 0.5 & 0.68 & 0.27 & & & & \\
\hline 21 & $33-40 \div 2$ & all 6 & 1.33 & 0.78 & 2.54 & 0.93 & -1.22 & -0.2 & & & & \\
\hline 22 & $33-41 \div 1$ & all 6 & 1.16 & 0.69 & 0.9 & 0.49 & 0.26 & 0.22 & & & & \\
\hline 23 & $33-41 \approx 2$ & all 3 & 1.16 & 0.69 & 1.14 & 0.63 & 0.01 & 0.05 & & & & \\
\hline 24 & Rectifier R1 & & & & & & & & & & & \\
\hline 25 & tap settings & $A-4$ & & & & & & & & & & \\
\hline 26 & volts & 21.6 & & & & & & & & & & \\
\hline 27 & amps & 13.2 & & & & & & & & & & \\
\hline 28 & efictency & & & & & & & & & & & \\
\hline 29 & $93-3$ & all 3 & 2.15 & 1.11 & 2.25 & 1.08 & -0.11 & 0.02 & 1.96 & 1.1 & 0.21 & -0.01 \\
\hline 30 & & g" RW & 0.79 & 0.39 & 0.9 & 0.4 & -0.11 & 0.02 & 0.58 & 0.41 & 0.21 & -0.01 \\
\hline 31 & & $4^{4} \mathrm{SW}$ & 1.04 & 0.57 & 1.15 & 0.54 & -0.11 & 0.02 & 0.83 & 0.59 & 0.21 & -0.01 \\
\hline 32 & $93-4$ & $11 / 2$ PAM7 & 2.43 & 1.17 & 2.61 & 1.15 & -0.19 & 0.01 & & & & \\
\hline 33 & & $4^{*} \mathrm{SW}$ & 1.15 & 0.7 & 1.31 & 0.74 & -0.19 & 0.01 & & & & \\
\hline 34 & & SN-650 & 2.45 & 1.17 & 2.63 & 1.18 & 0.19 & 0.01 & & & & \\
\hline 35 & & $14^{\prime \prime} \mathrm{RW}$ & 1.62 & 1.02 & 1.78 & 1.02 & -0.19 & 0.01 & & & & \\
\hline 36 & A farm & 1994 & 1994 & 1994 & 1994 & 1994 & 1994 & 1994 & 1994 & 1994 & 1994 & 1994 \\
\hline 37 & Aren & & & & & & & & & & & \\
\hline 38 & Rectifier 18 & & & & & & & & & & & \\
\hline 39 & $42-16$ & both & 5.15 & 1.75 & 4.23 & 1.86 & 0.73 & -0.07 & & & & \\
\hline 40 & $42-17$ & all 6 & 5.41 & 1.85 & 3.77 & 1.63 & 1.64 & 0.2 & & & & \\
\hline 41 & $42-18$ & all 5 & 1.94 & 0.92 & 3.38 & 1.23 & -1.44 & -0.23 & 1.02 & 0.77 & 0.92 & 0.16 \\
\hline 42 & $42-19$ & all 6 & 1.43 & 0.87 & 2.12 & 1.17 & -0.68 & 0.28 & 2.12 & 1.08 & -0.69 & -0.17 \\
\hline 43 & $42-20$ & & & & & & & & & & & \\
\hline 44 & $42-21 \div 1$ & all 5 & 2.54 & 1.11 & 1.34 & 0.89 & 1.2 & 0.22 & & & & \\
\hline 45 & $42-21 \div 2$ & atil 4 & 2.54 & 1.11 & 2.31 & 1.09 & 0.22 & 0.02 & & & & \\
\hline 48 & $42-38$ & & & & & & & & & & & \\
\hline 47 & $42-39$ & & & & & & & & & & & \\
\hline 48 & $42-40$ & all 6 & 2.81 & 1.06 & 2.9 & 1.09 & -0.1 & -0.03 & & & & \\
\hline 49 & & & & & & & & & & & & \\
\hline 50 & AW farm & 1994 & 1994 & 1994 & 1994 & 1994 & 1994 & 1994 & 1994 & 1994 & 1994 & 1994 \\
\hline 51 & Arel & & & & & & & & & & & \\
\hline 52 & Rectifier 19 & & & & & & & & & & & \\
\hline 53 & tap settings & B-4 & & & & & & & & & & \\
\hline 54 & volts & 10.5 & & & & & & & & & & \\
\hline 55 & amps & 4.7 & & & & & & & & & & \\
\hline 58 & efificiency & & & & & & & & & & & \\
\hline 57 & 33-17 & both & 0.82 & 0.58 & & & & & & & & \\
\hline 58 & $33-22$ & both & 1.12 & 0.78 & & & & & & & & \\
\hline 59 & $33-27 \geqslant 1$ & all & 1.44 & 0.77 & & & & & & & & \\
\hline 60 & $33-27<2$ & all & 1.45 & 0.76 & & & & & & & & \\
\hline 61 & $33-34$ & ons & 0.89 & 0.73 & 1.21 & 0.83 & & & 0.84 & 0.62 & & \\
\hline 62 & $33-35$ & all & 2.04 & 1.09 & 1.95 & 0.9 & 0.09 & & & & & \\
\hline 63 & $33-37$ & alli & 1.63 & 0.96 & 1.38 & 0.8 & 0.44 & & & & & \\
\hline
\end{tabular}




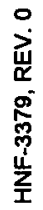

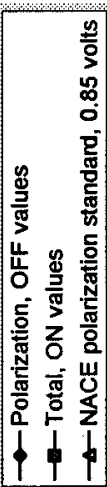

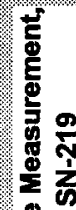

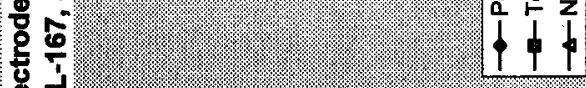

II

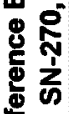

व

\%

$\frac{1}{8}$

용

क

$\frac{8}{2}$

녕

온

음

บ

แ

\%

$\vec{\infty}$

$\underset{\omega}{\infty}$

$\approx 5$

도유

क

苛

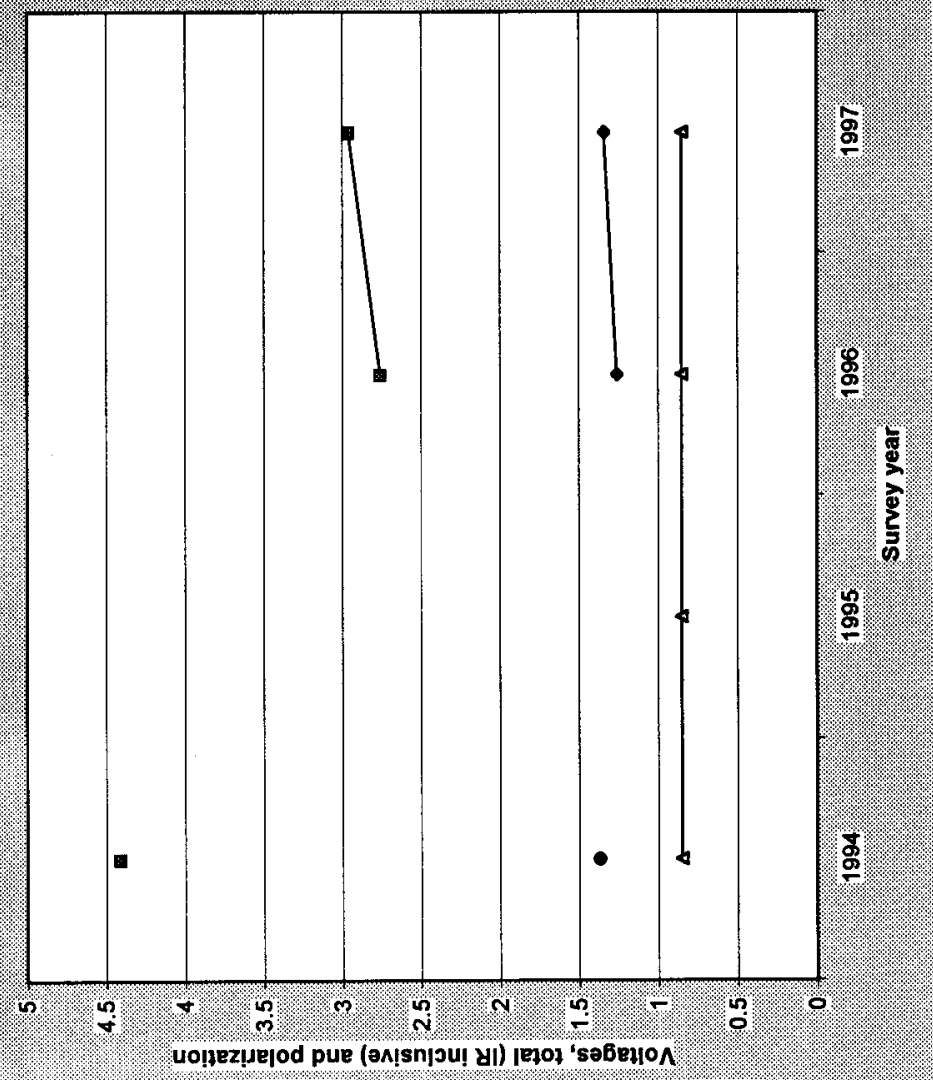

$-23-$ 


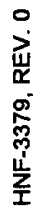
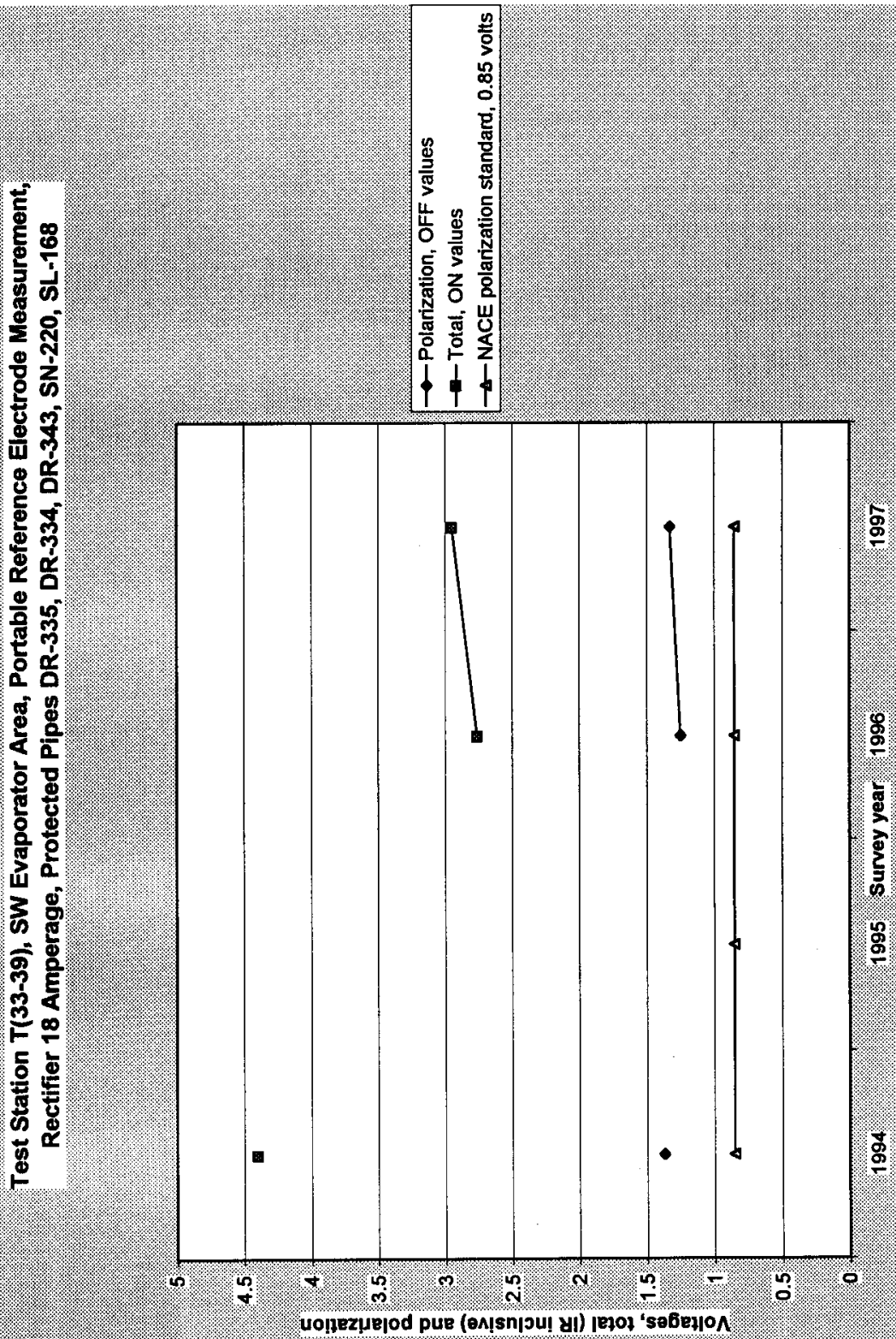


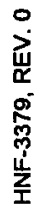

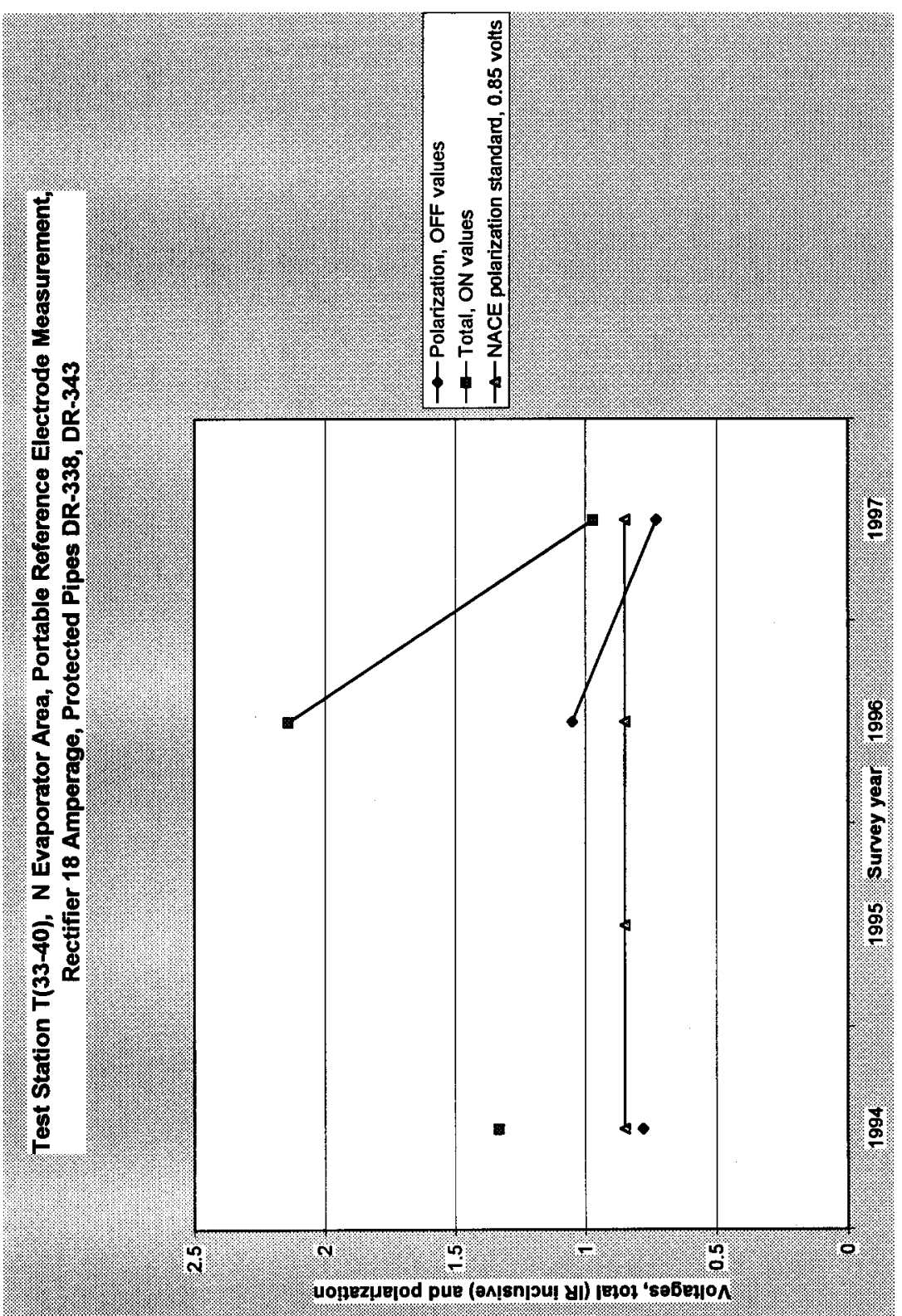


0
㟧
$\frac{1}{8}$
$\frac{7}{7}$
$\frac{1}{2}$
$\frac{2}{2}$

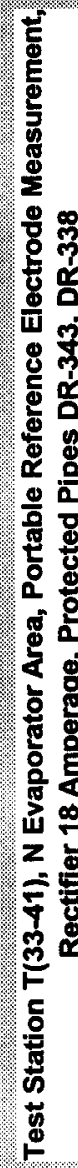

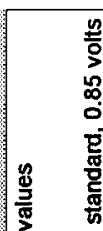

능 \&

동 焉

害 $\mathrm{z} \frac{0}{8}$

空 西

응

政

tht

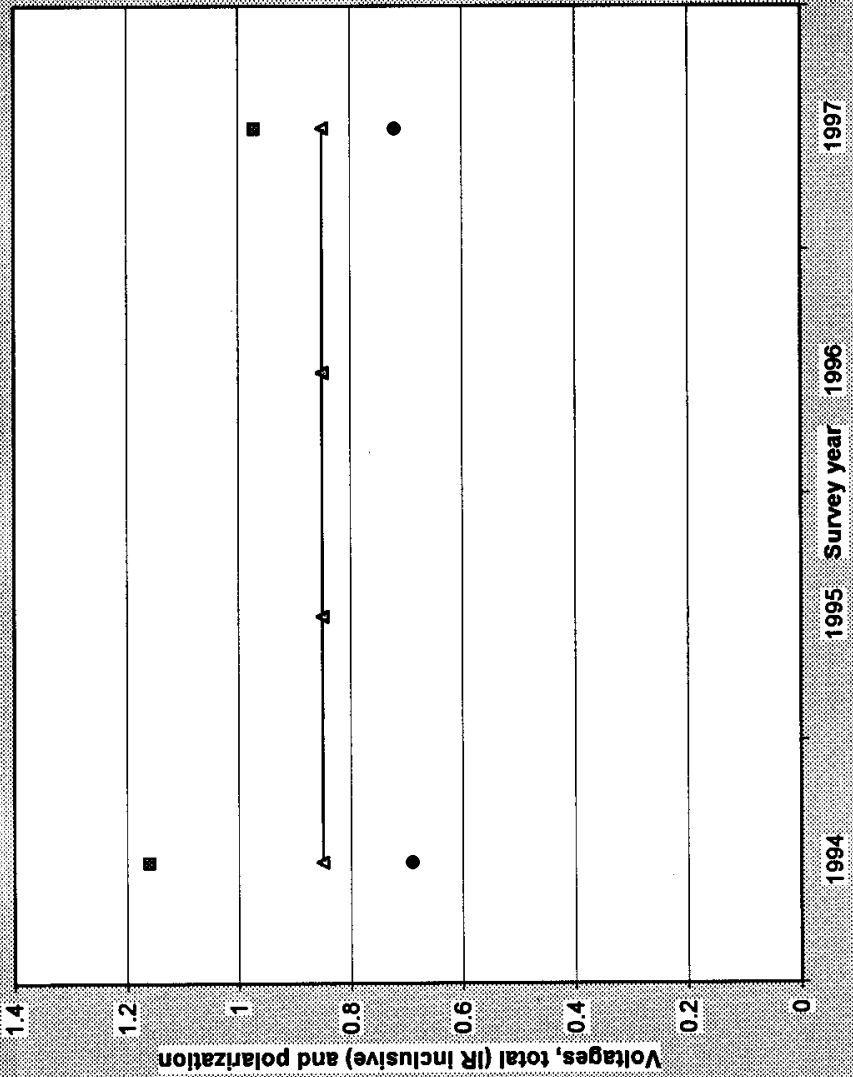




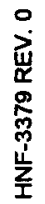

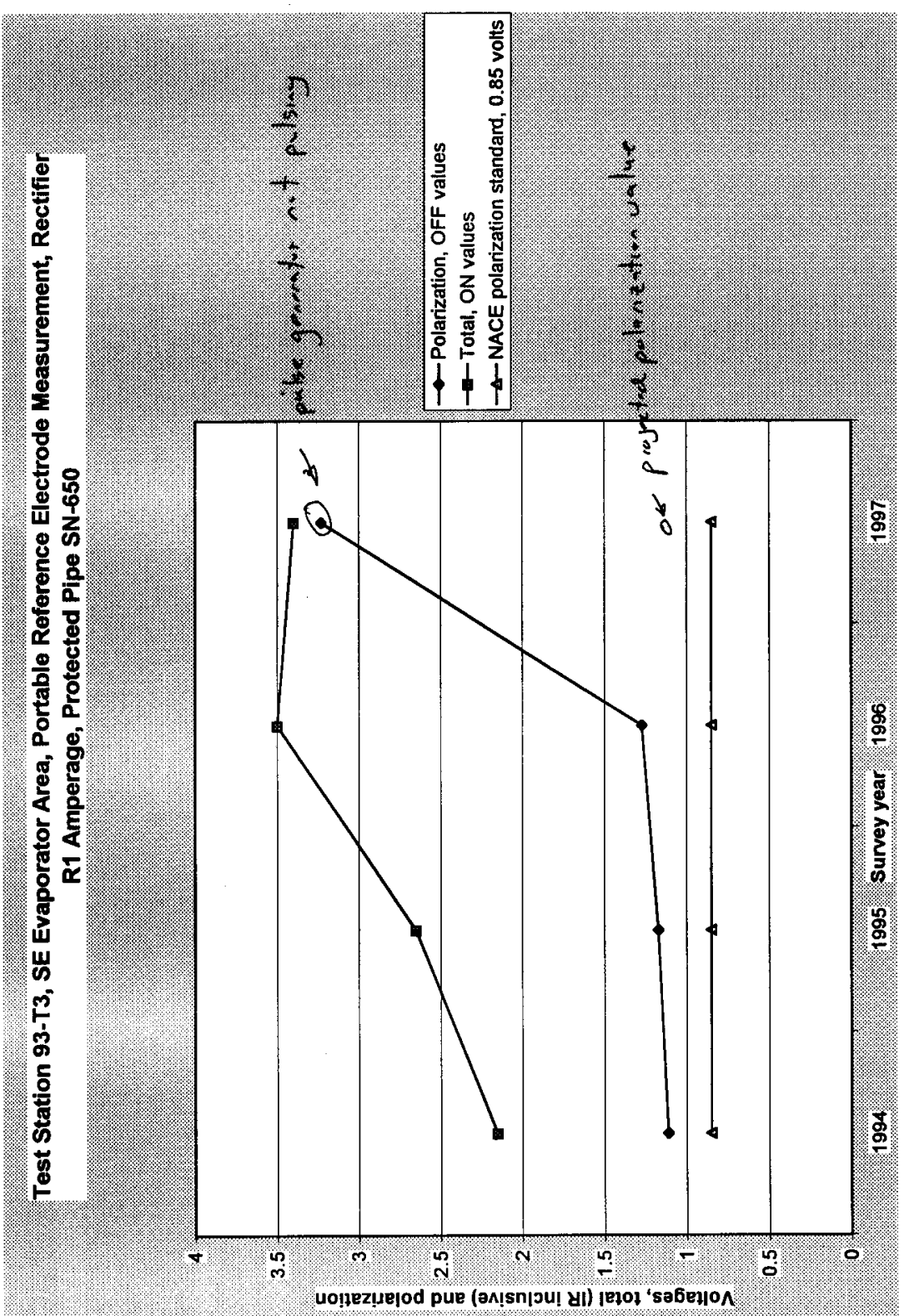




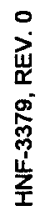

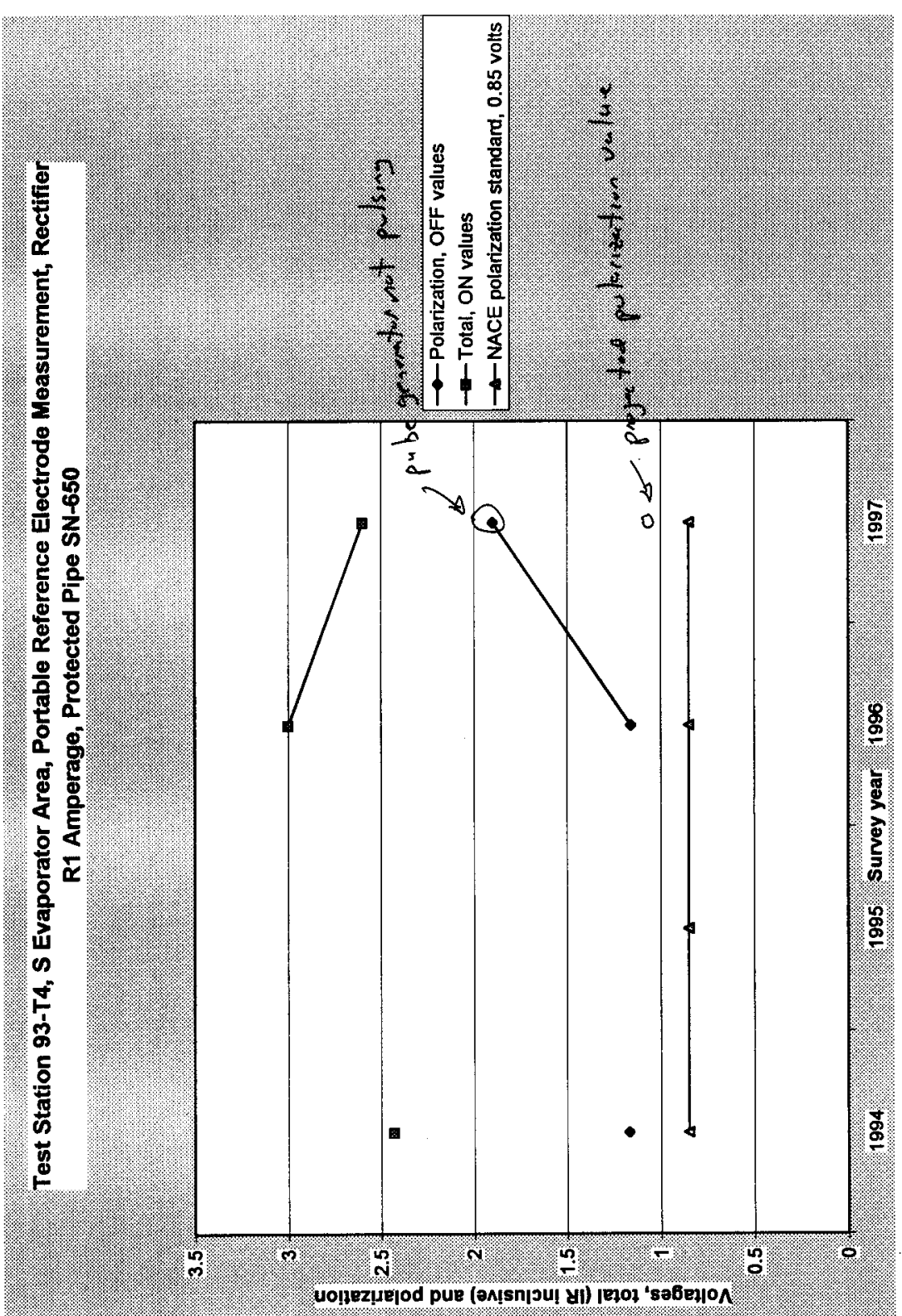

$-28-$ 
竞

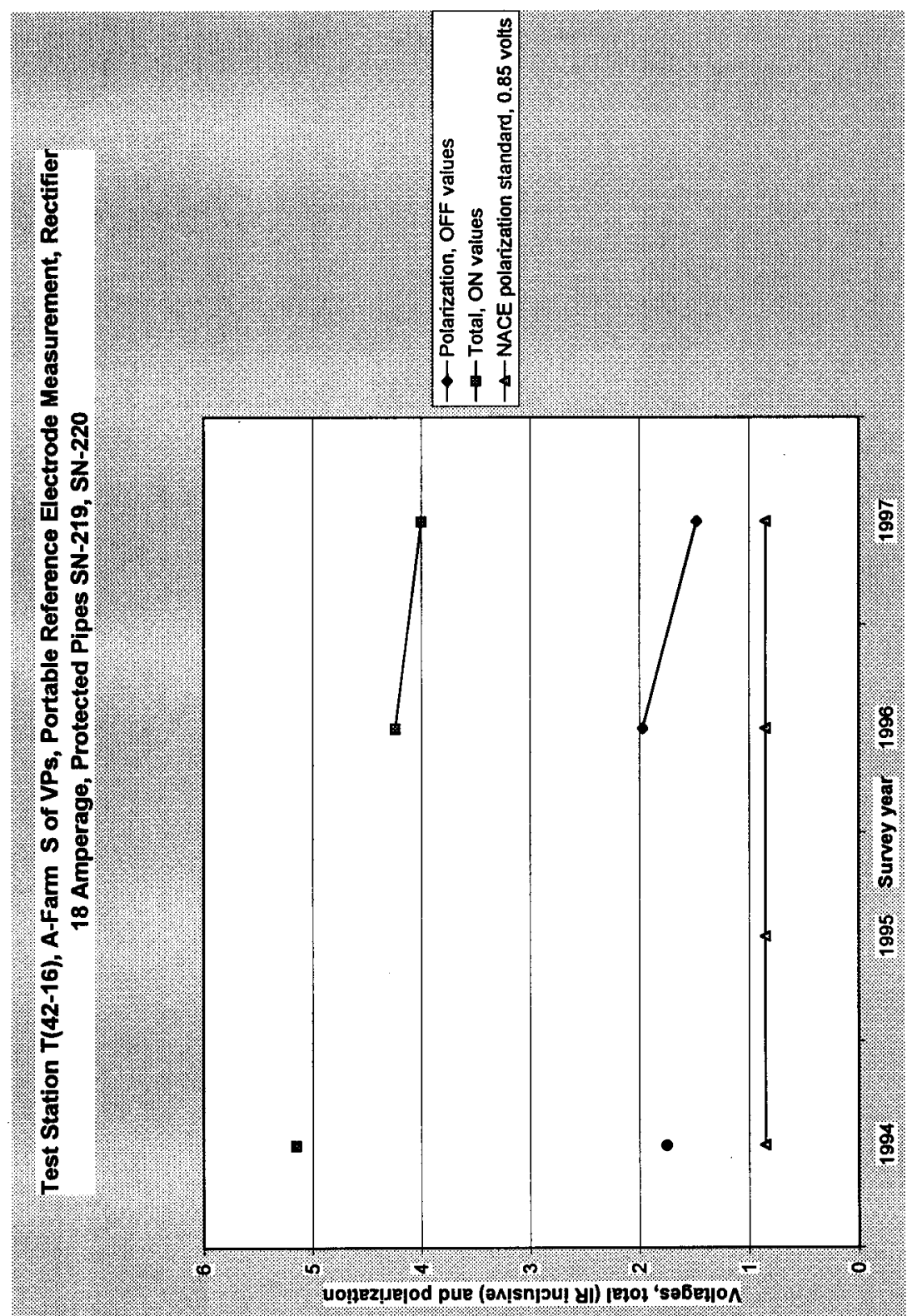




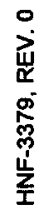

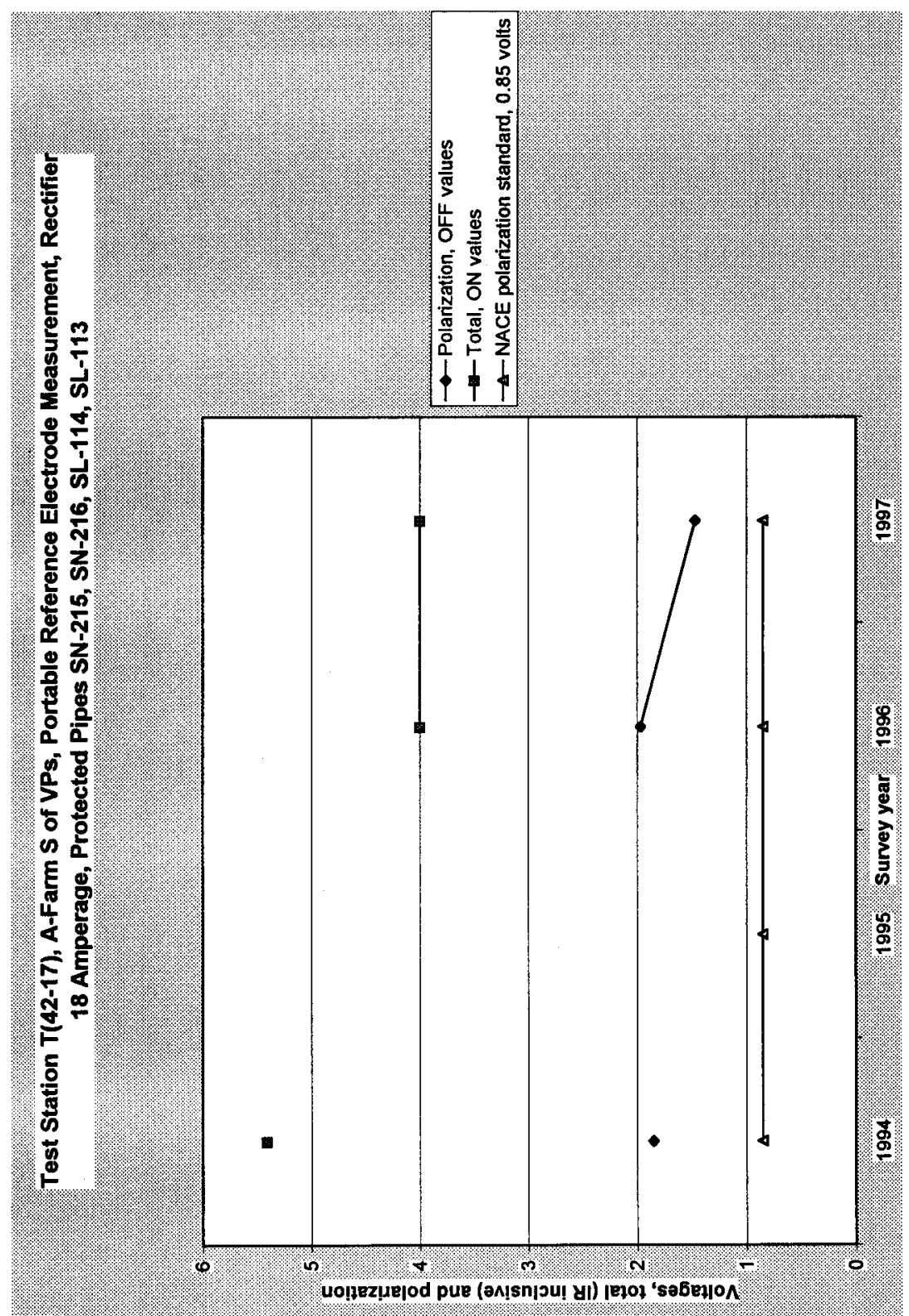




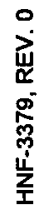

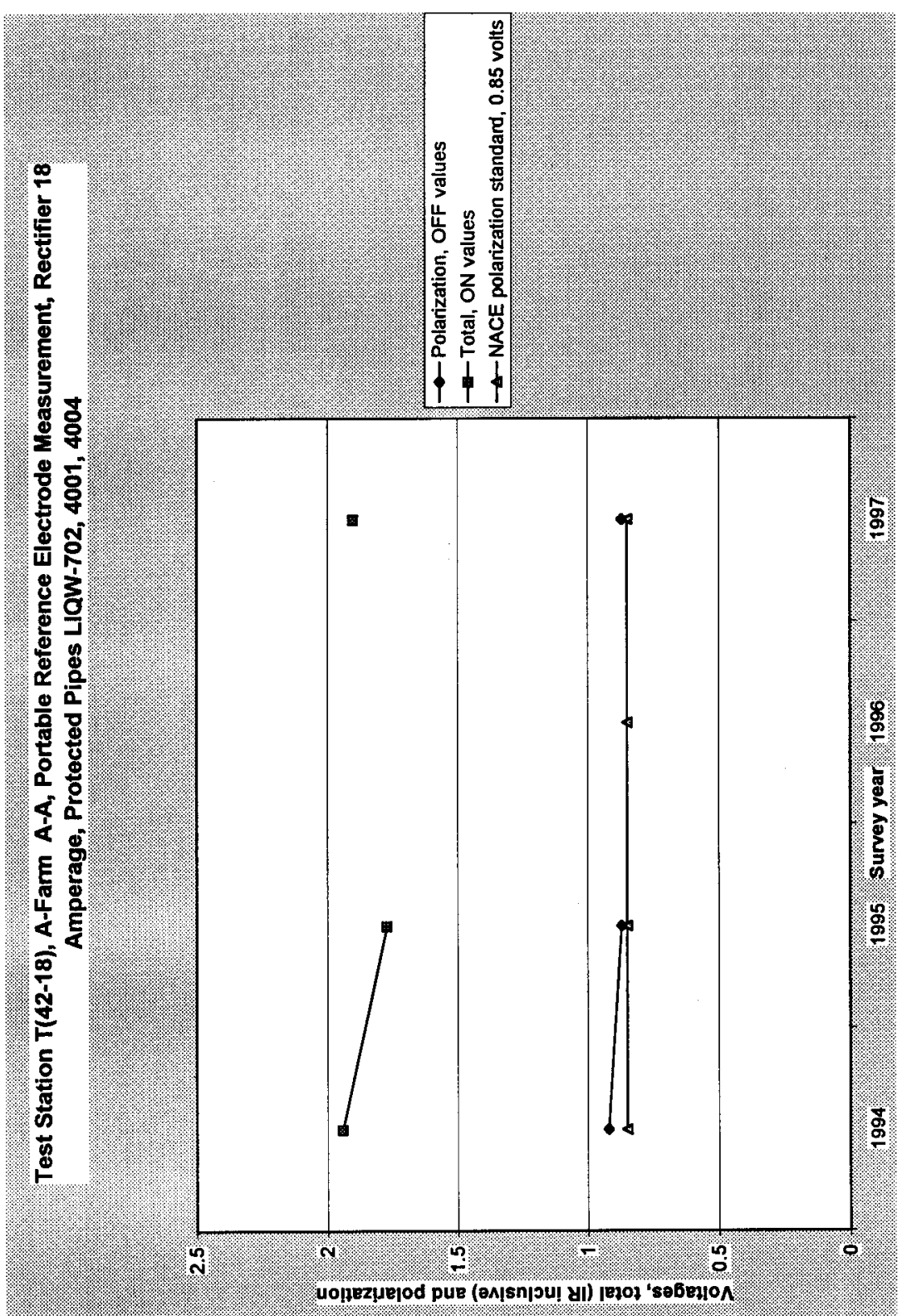




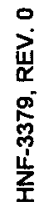

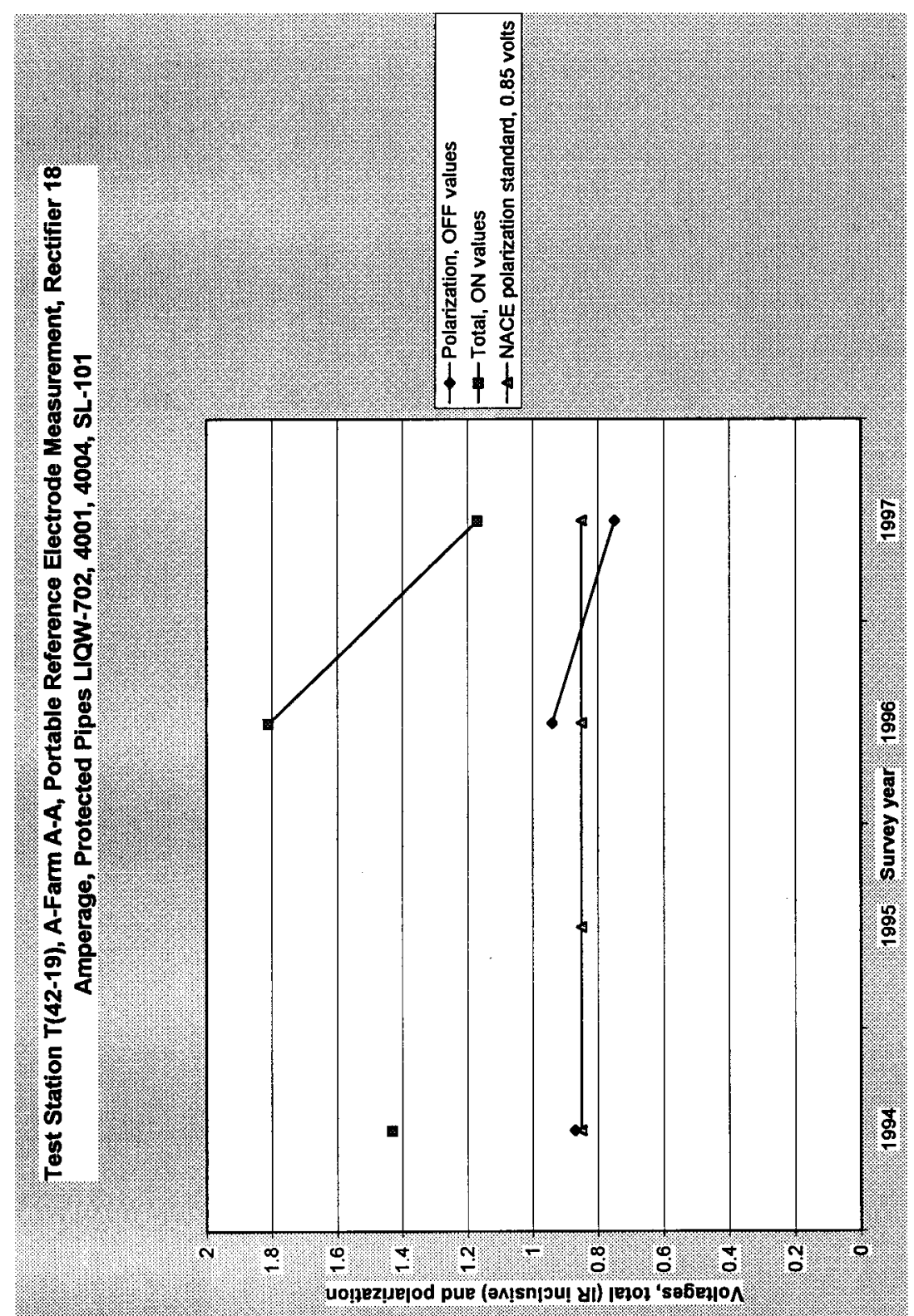


竞

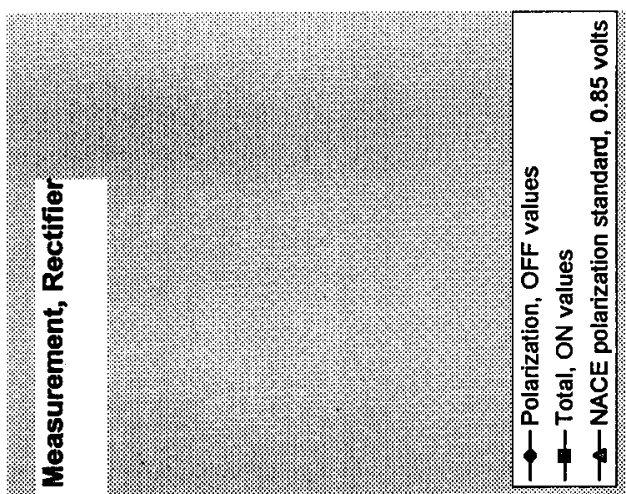

$\frac{8}{8} \frac{5}{8} \frac{1}{b}$

ш

递宁

क्ष

$\frac{1}{0}$

$\frac{0}{0}$

on 2

$\sum_{0}^{0}$

$2 \Phi$

E

누

$\frac{\bar{y}}{y}$

F

5
0
0
0
0
0
0
0

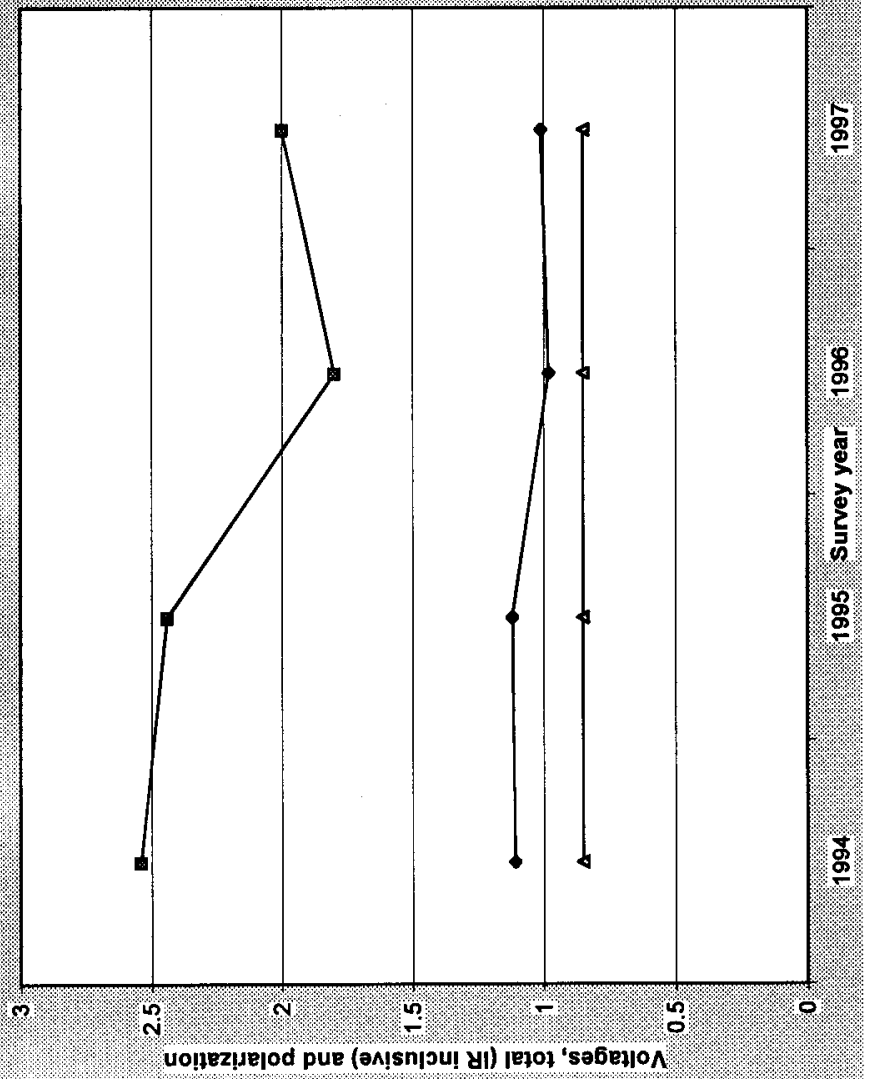




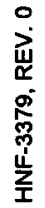

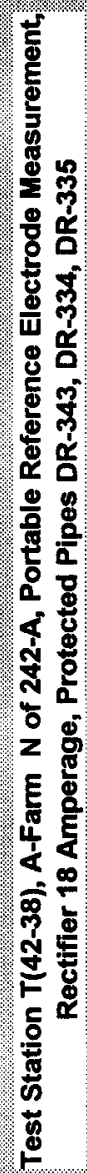

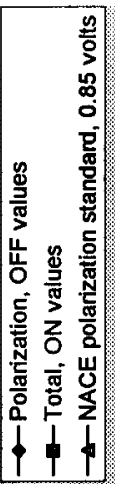

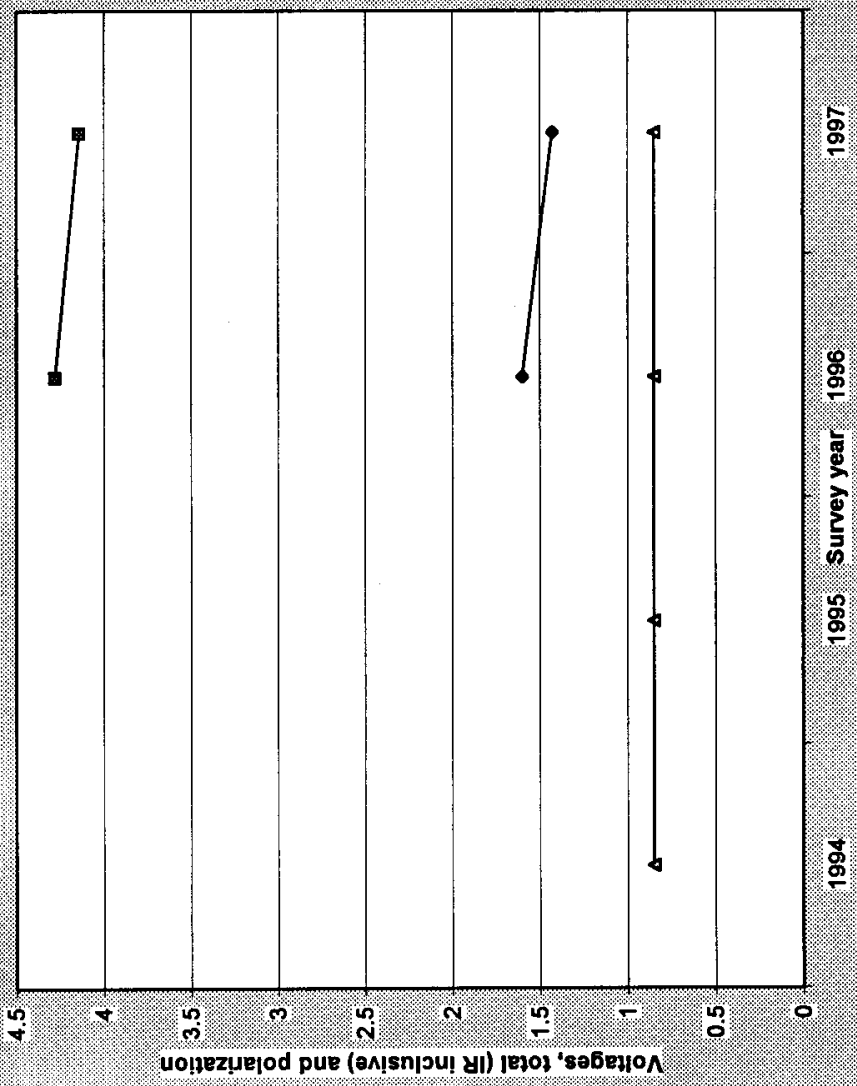




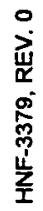

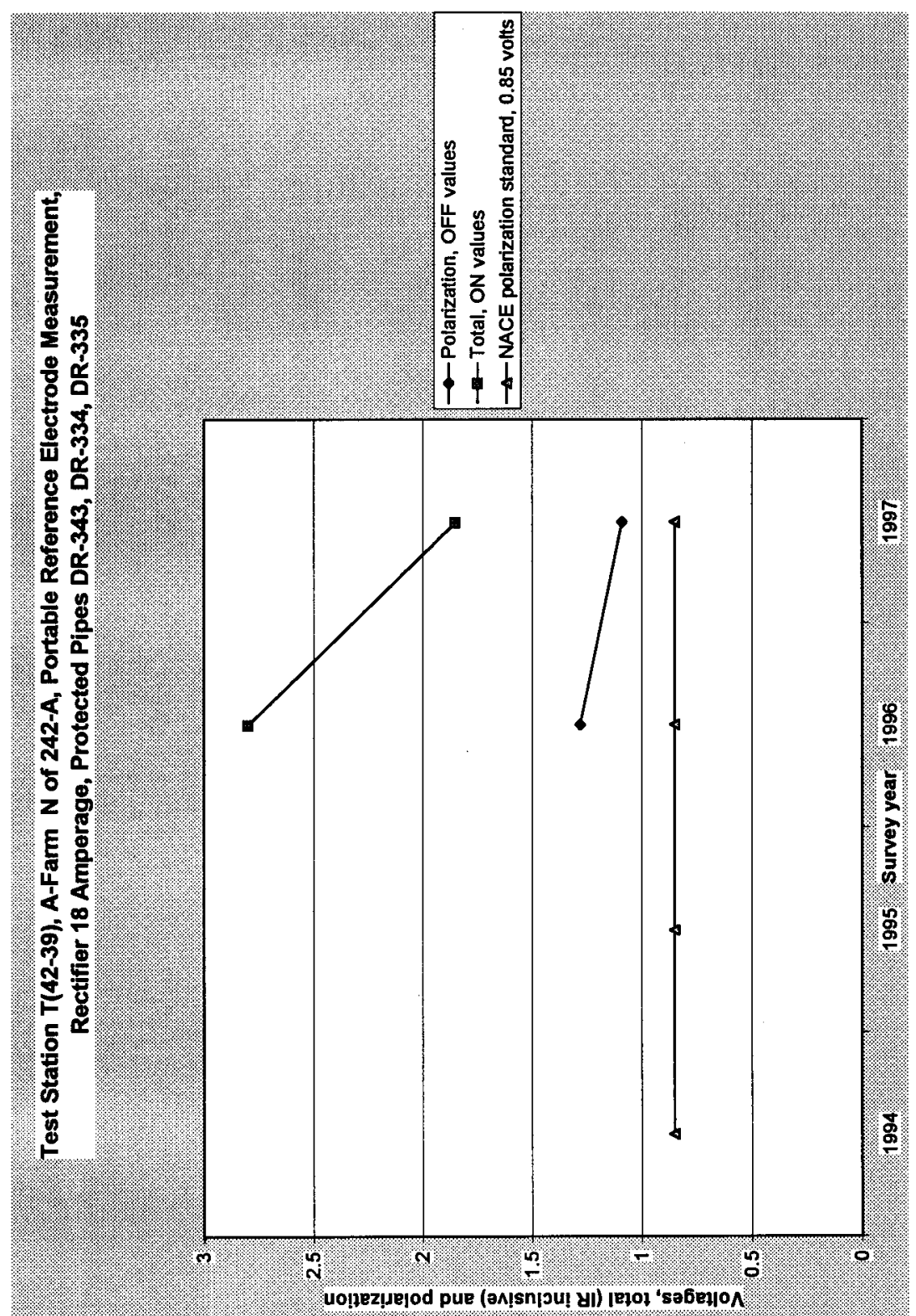


0
㟧
$\rho^{-}$
$\frac{0}{0}$
$\frac{1}{2}$
$\frac{1}{2}$

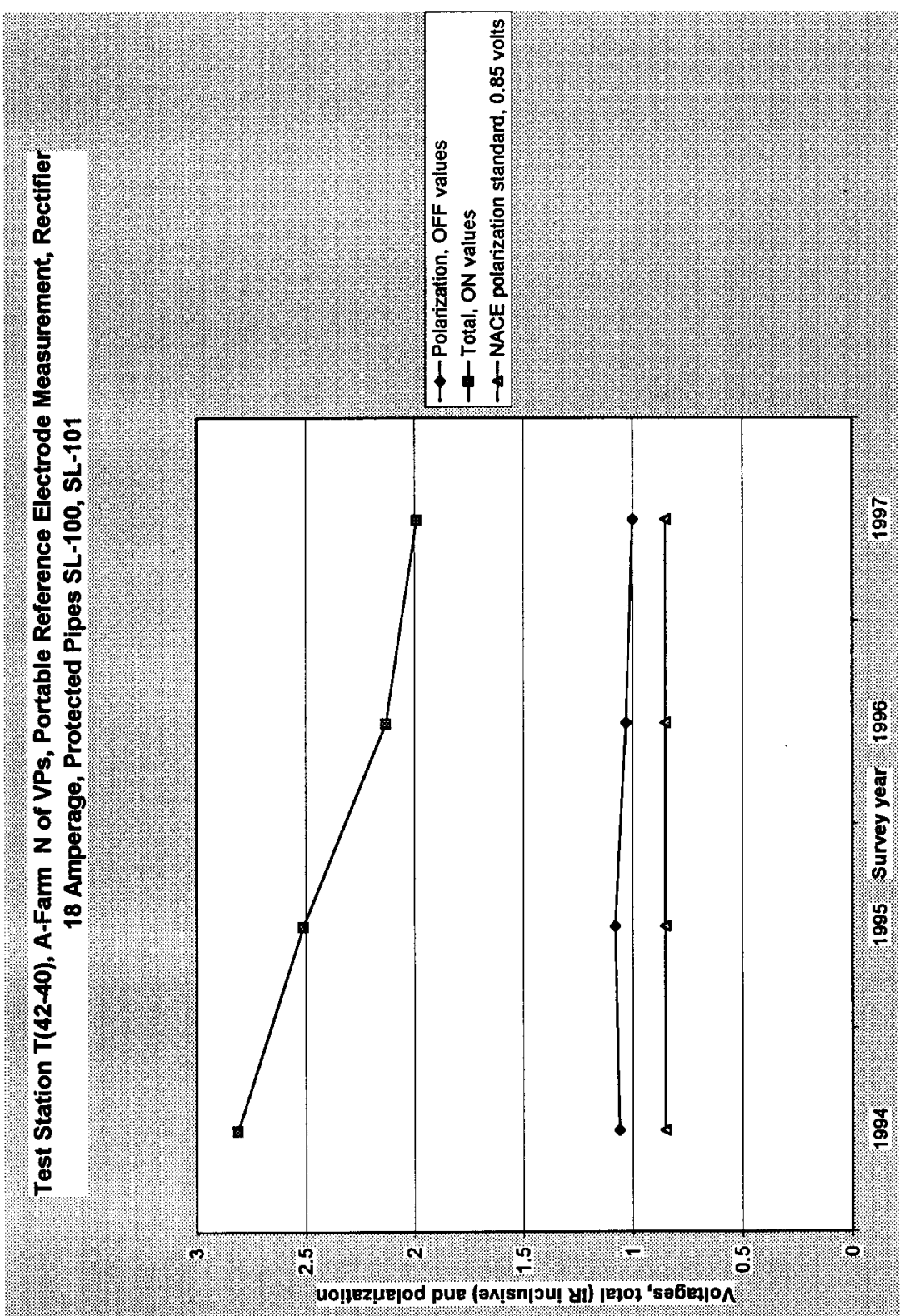

$-36=$ 


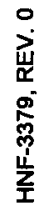

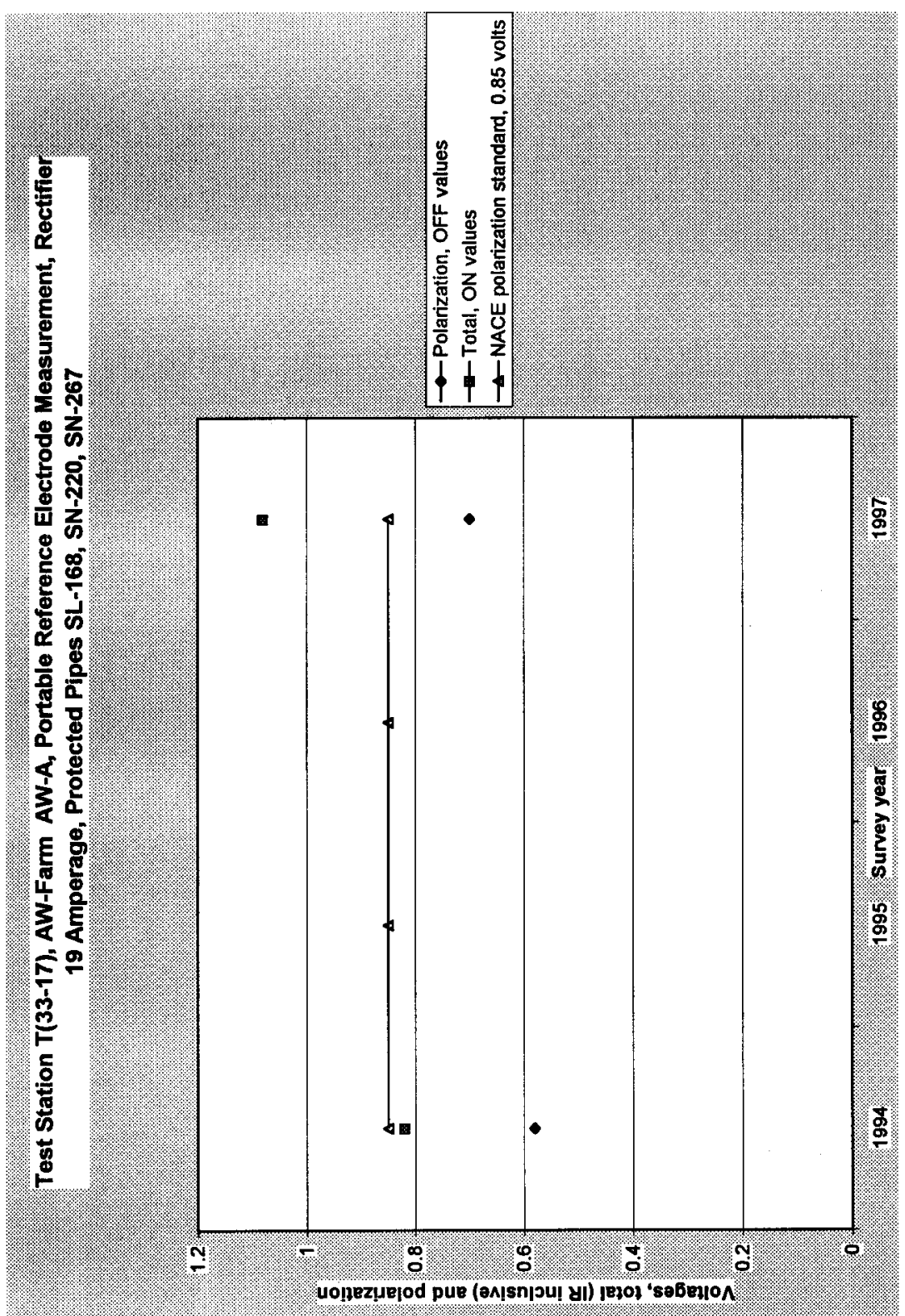




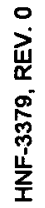

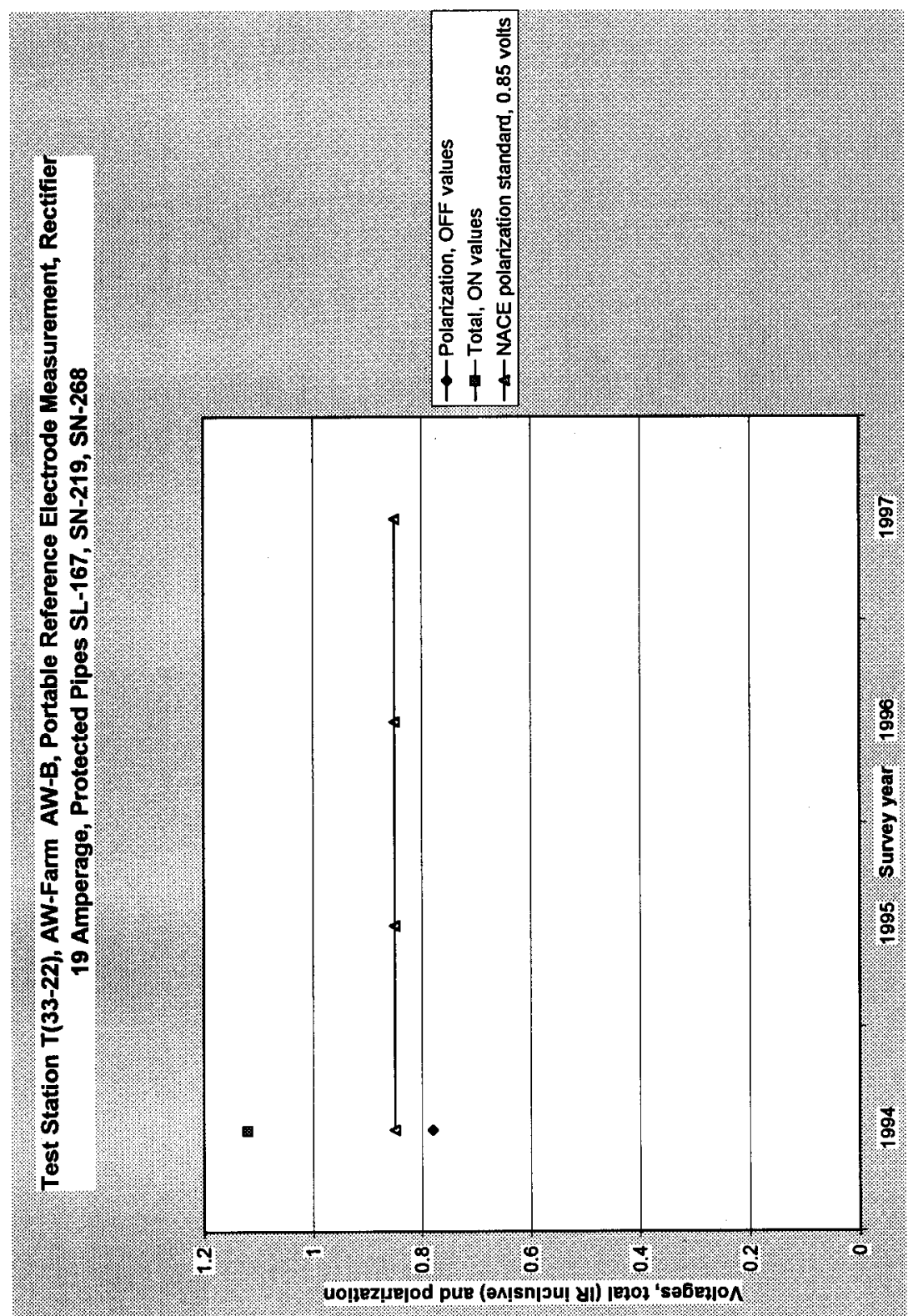


㟧
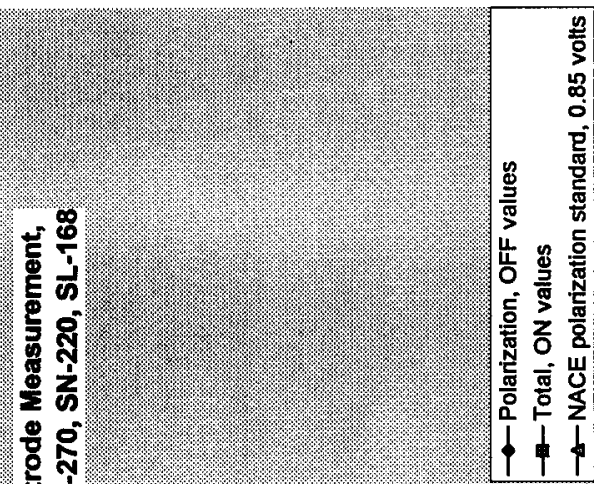

옹

过

Ш

$\frac{1}{2} \frac{1}{b}$

$\stackrel{\circ}{\circ}$

-

$\frac{7}{n}$

$\frac{2}{2} 5$

के

$\sum_{5}^{2}$

2

E

$\frac{1}{3}$.

$\approx 0$

พ

ल

룽

웅

万人

舟

o

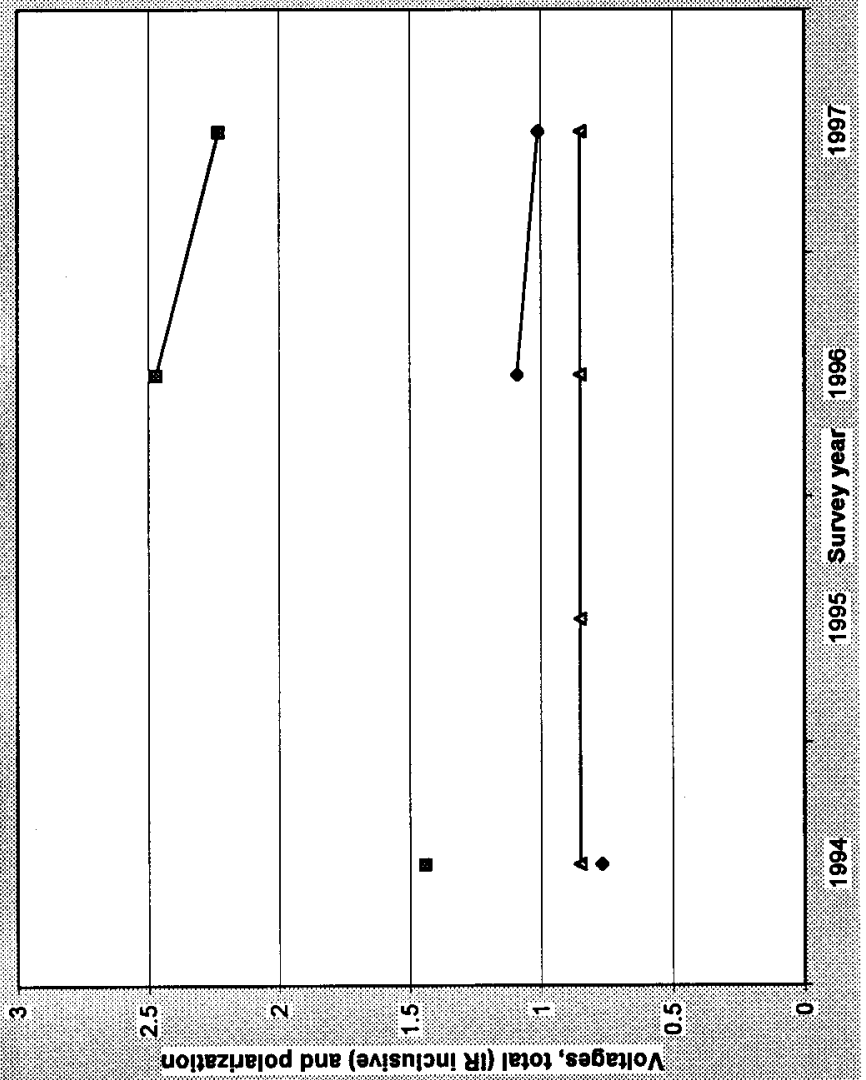




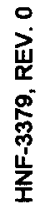

涉

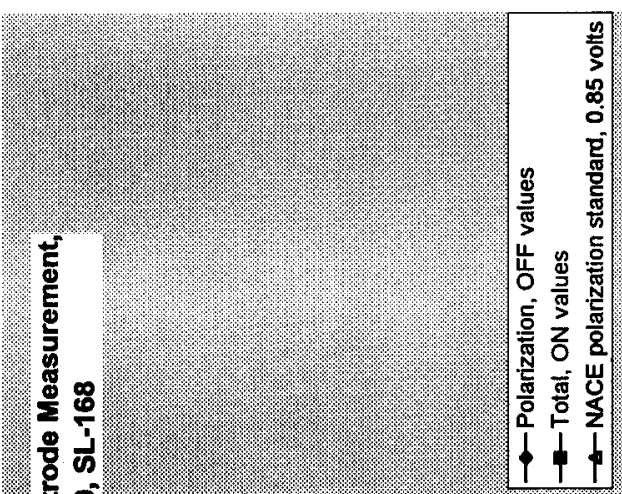

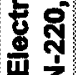

\&

$\frac{5}{0} \frac{5}{5}$

व

용용

능

․ 8

5 응

प a

z

E

㞱

क

के

क

$=$
c

$\frac{0}{4}$

पू

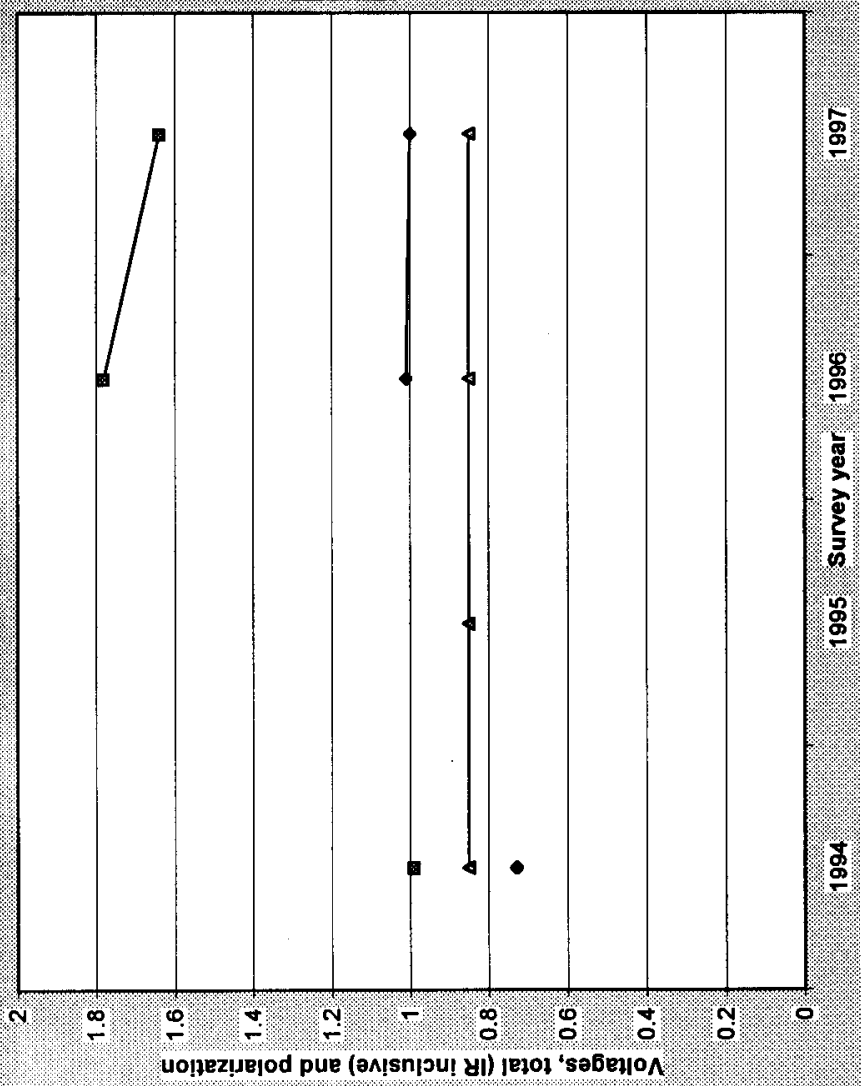




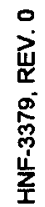

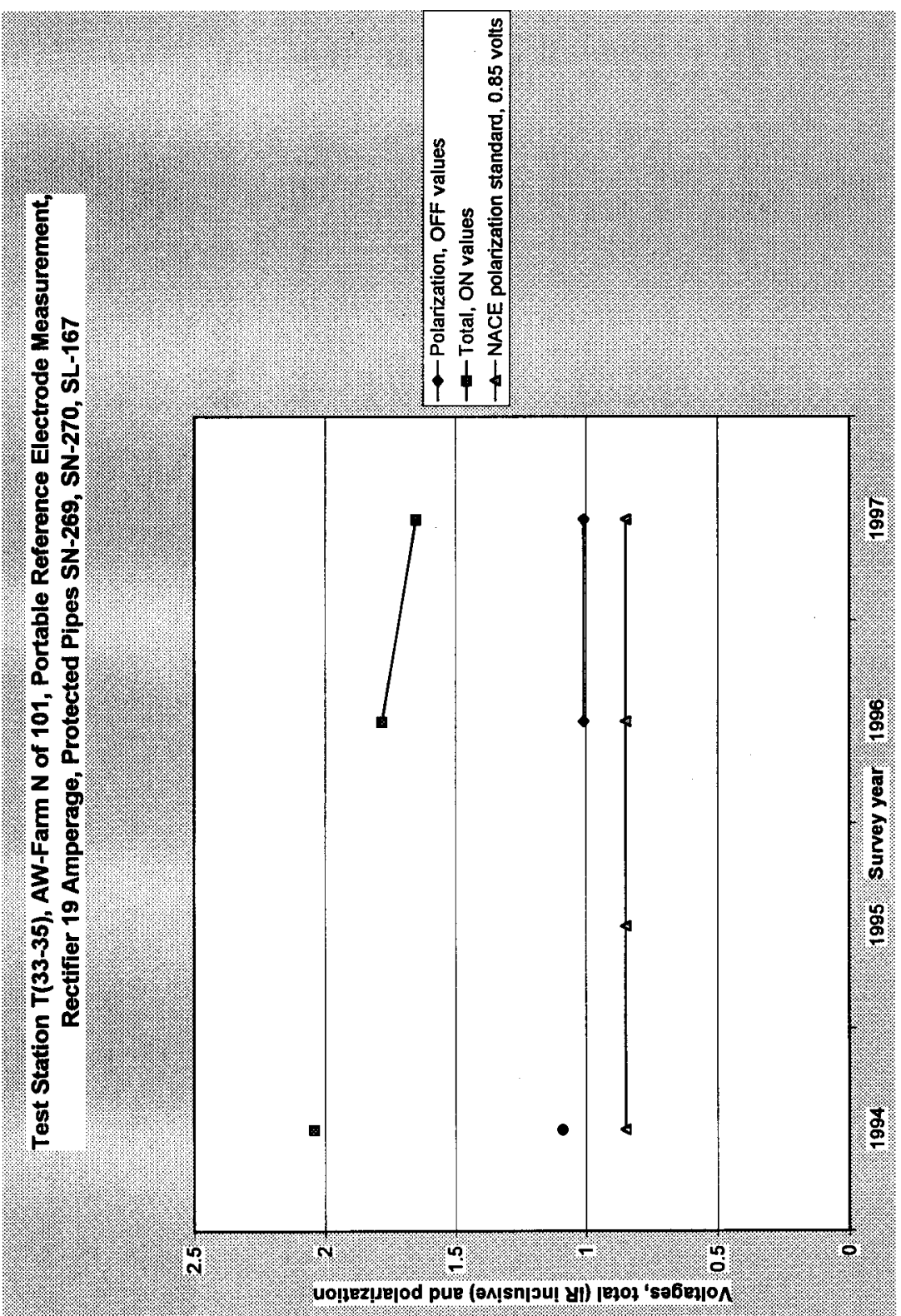




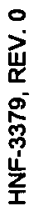

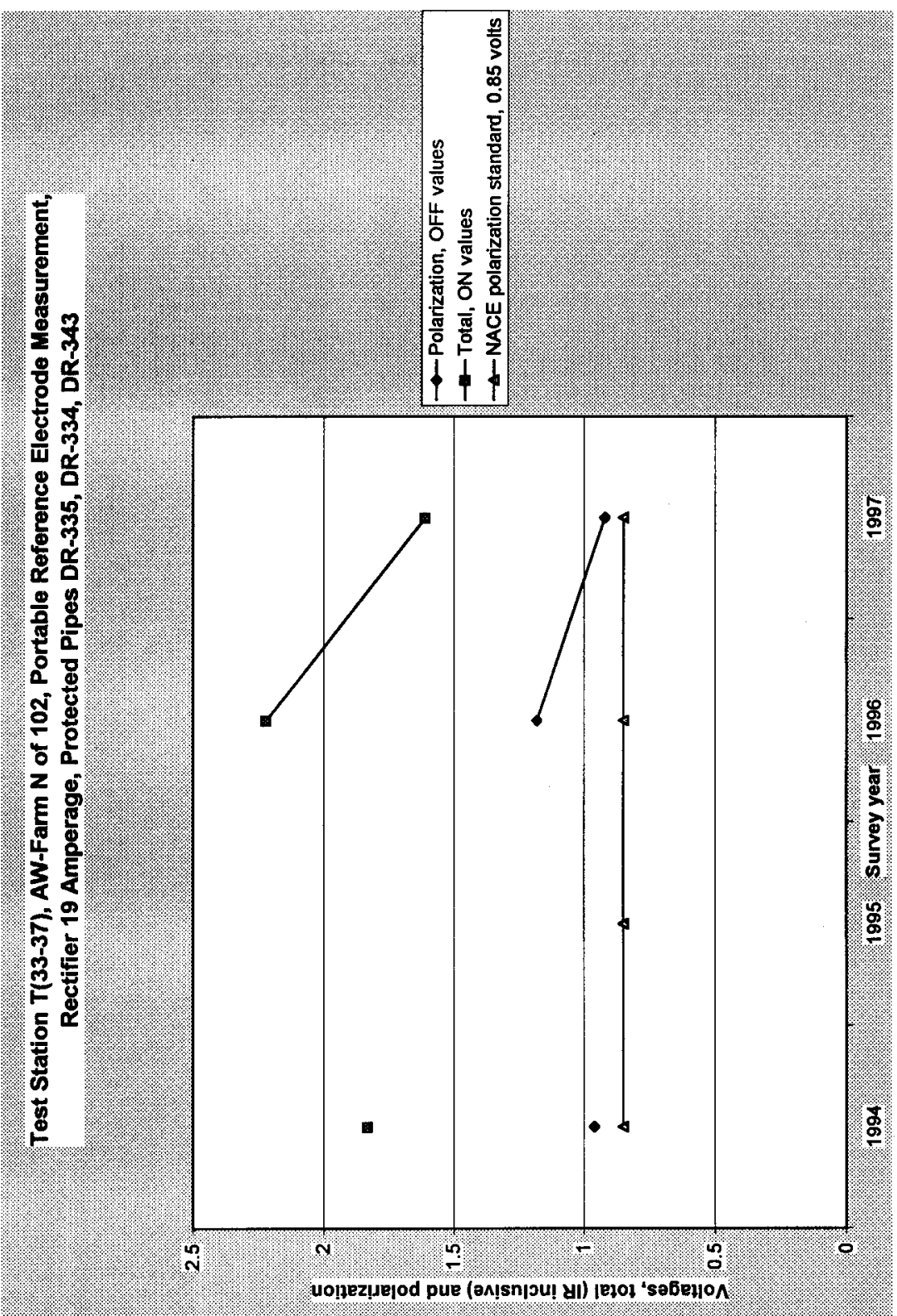




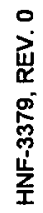

$\begin{array}{ll}0 & \frac{2}{2} \\ \text { के } & \frac{E}{\alpha} \\ 0 & 0 \\ 0 & 0 \\ 1 & 1\end{array}$

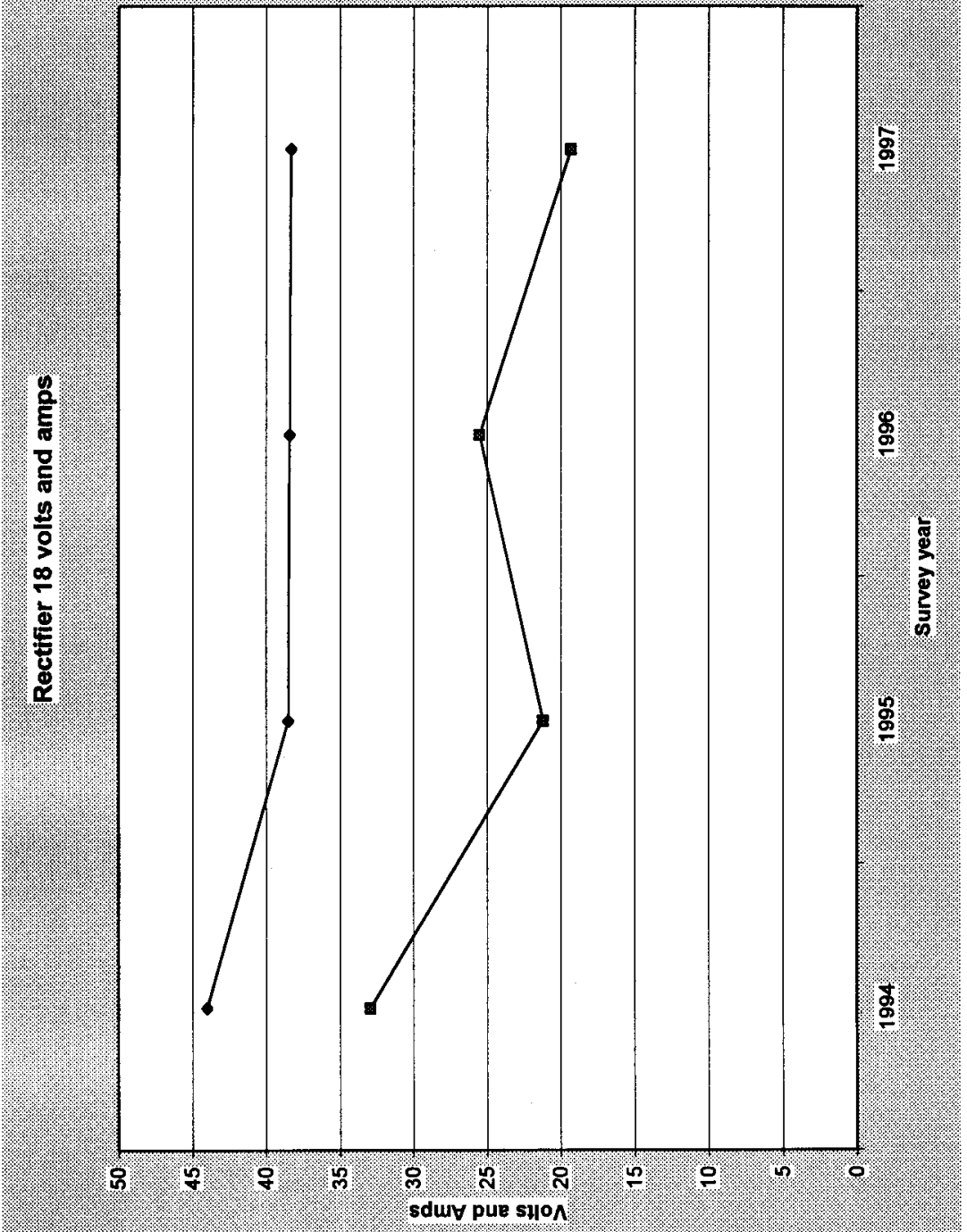

$-43-$ 


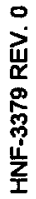
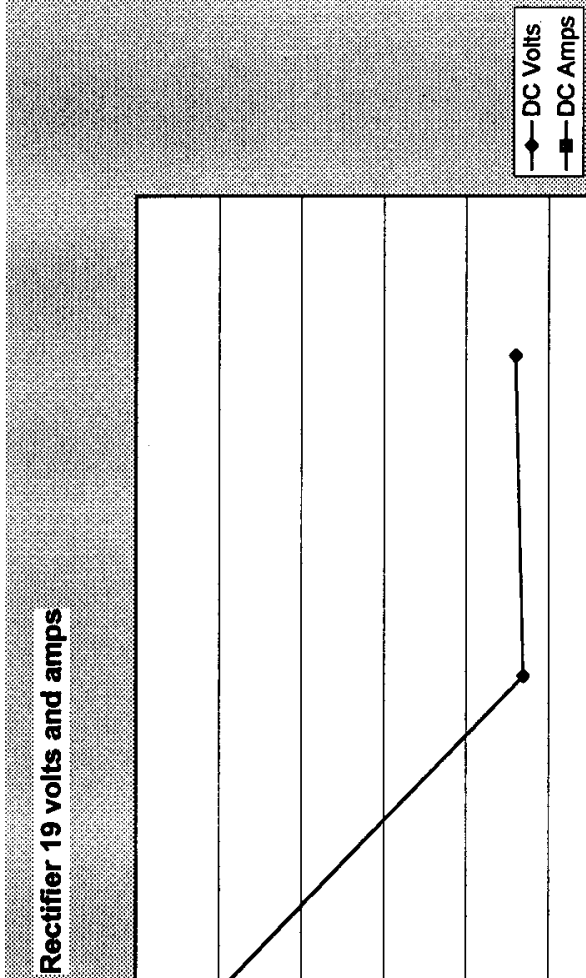

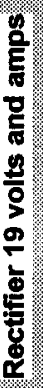
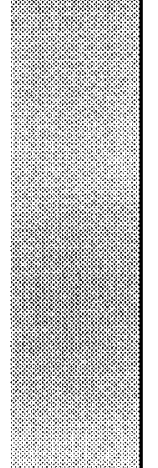

8

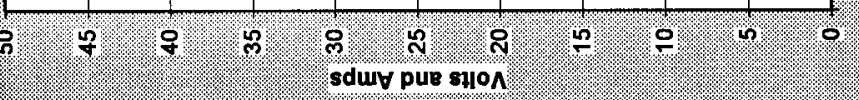




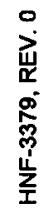
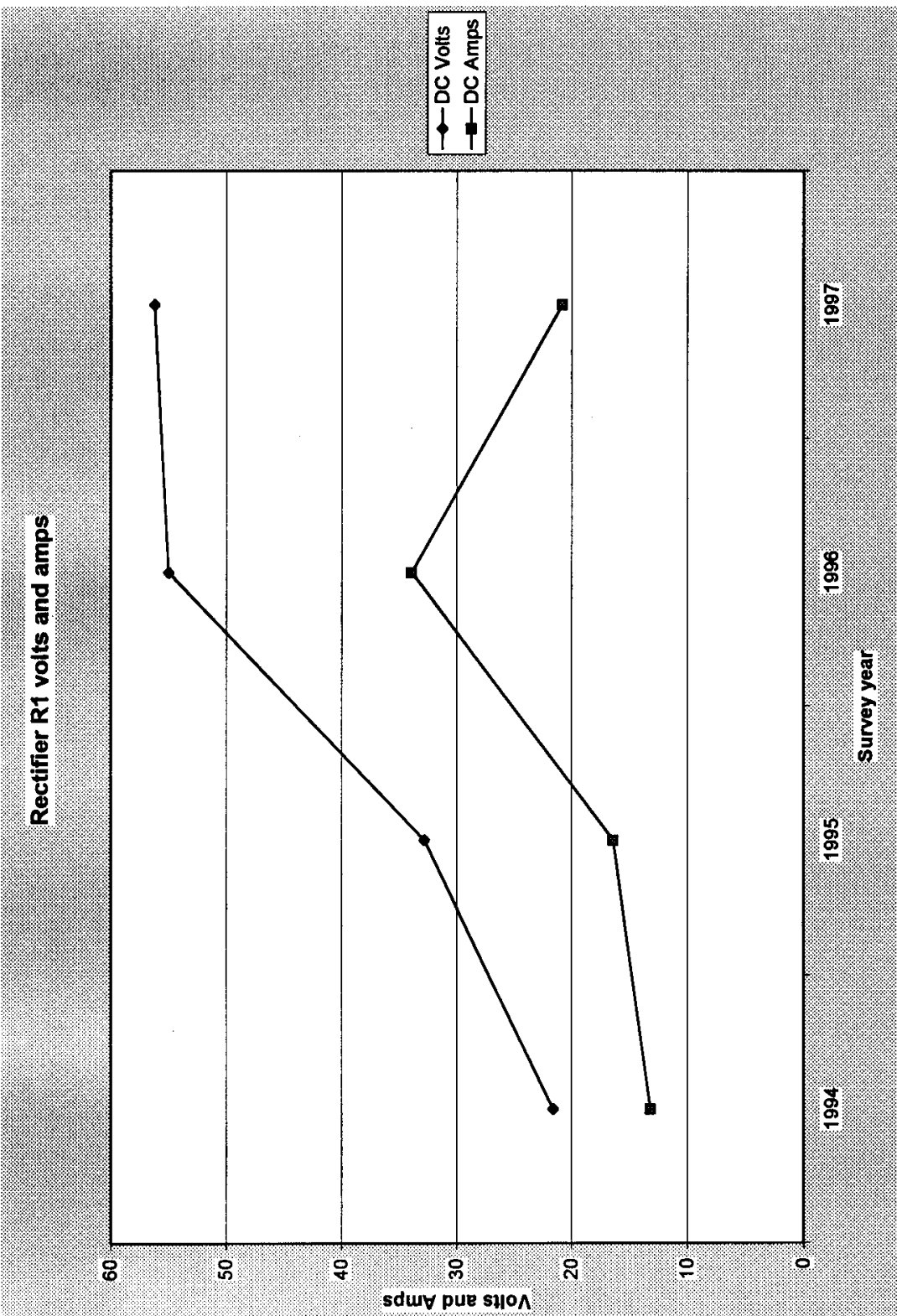

$-45-$ 


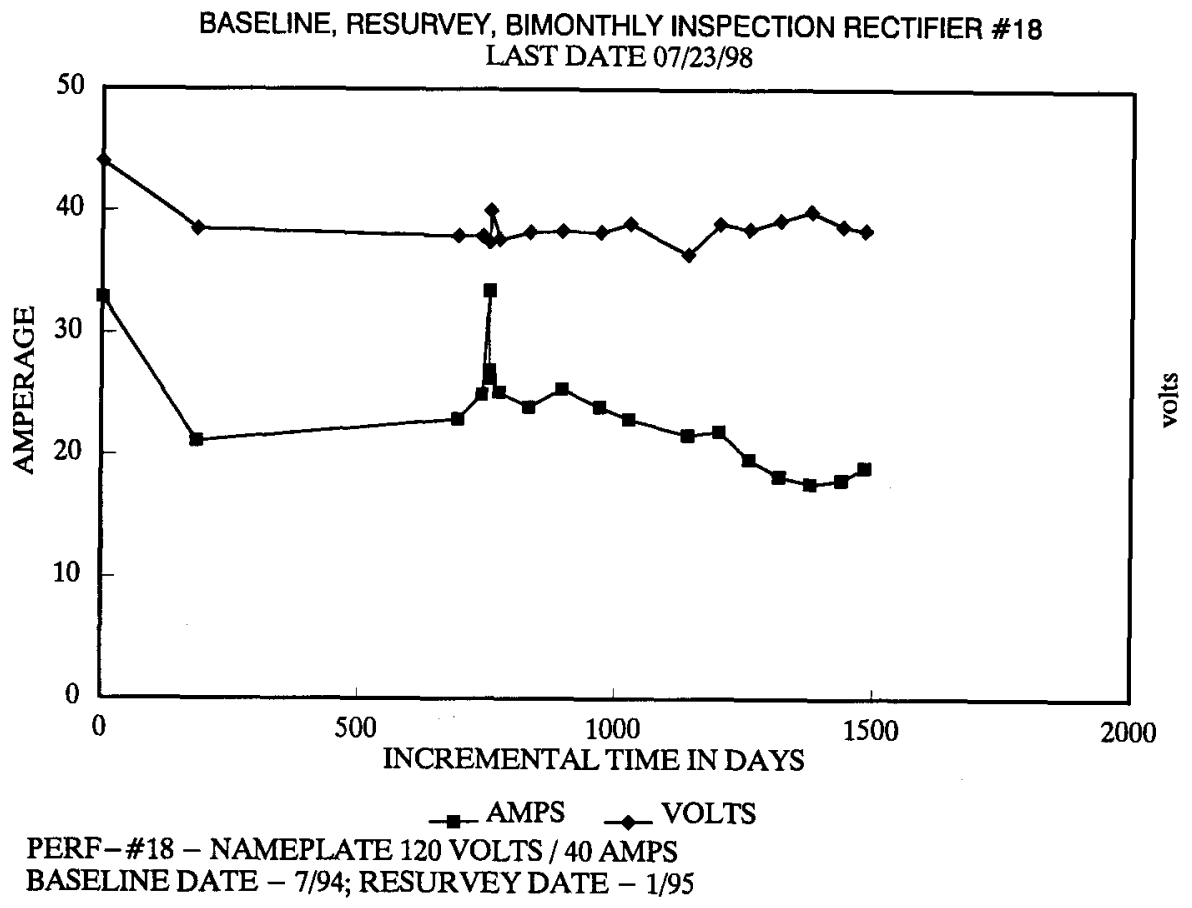


HNF-3379, REU.O

\section{BASELINE, RESURVEY, BIMONTHLY \#19}

\section{LAST DATE $7 / 7 / 98$}

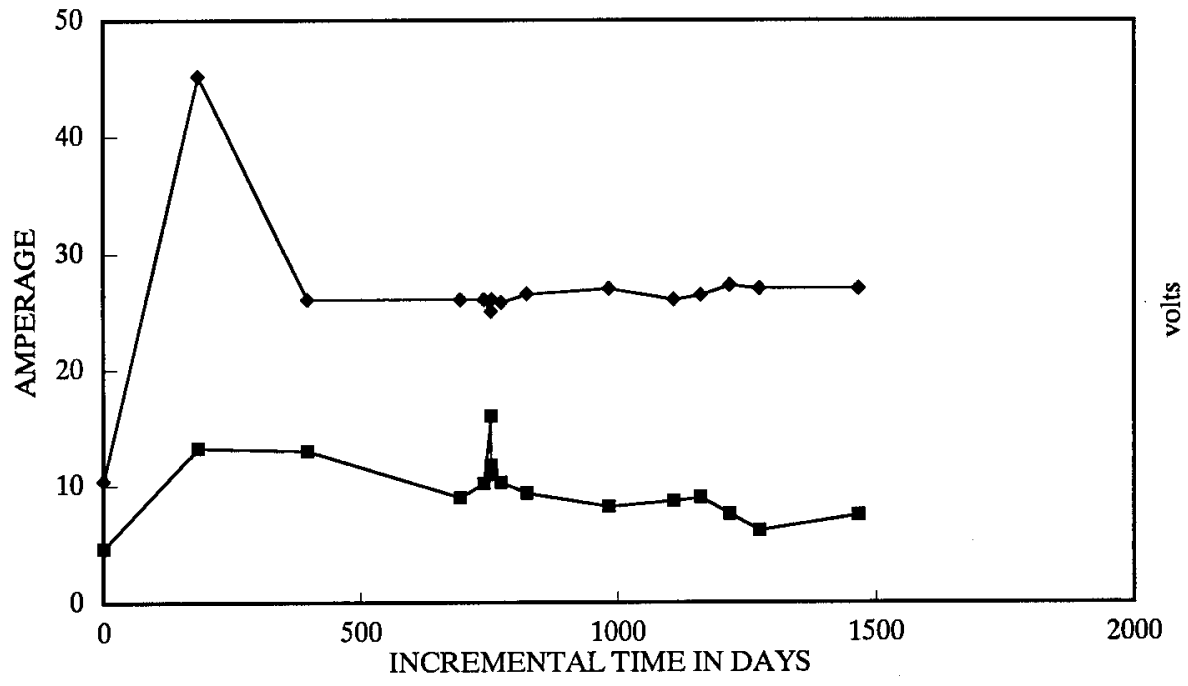

$\rightarrow$ AMPS $\rightarrow$ VOLTS

PERF-\#19 - NAMEPLATE 40 VOLTS / 12 AMPS

BASELINE DATE - 7/94; RESURVEY DATE - 1/95 


\section{BASELINE, RESURVEY, BIMONTHLY \#R1} LAST DATE 7/7/98

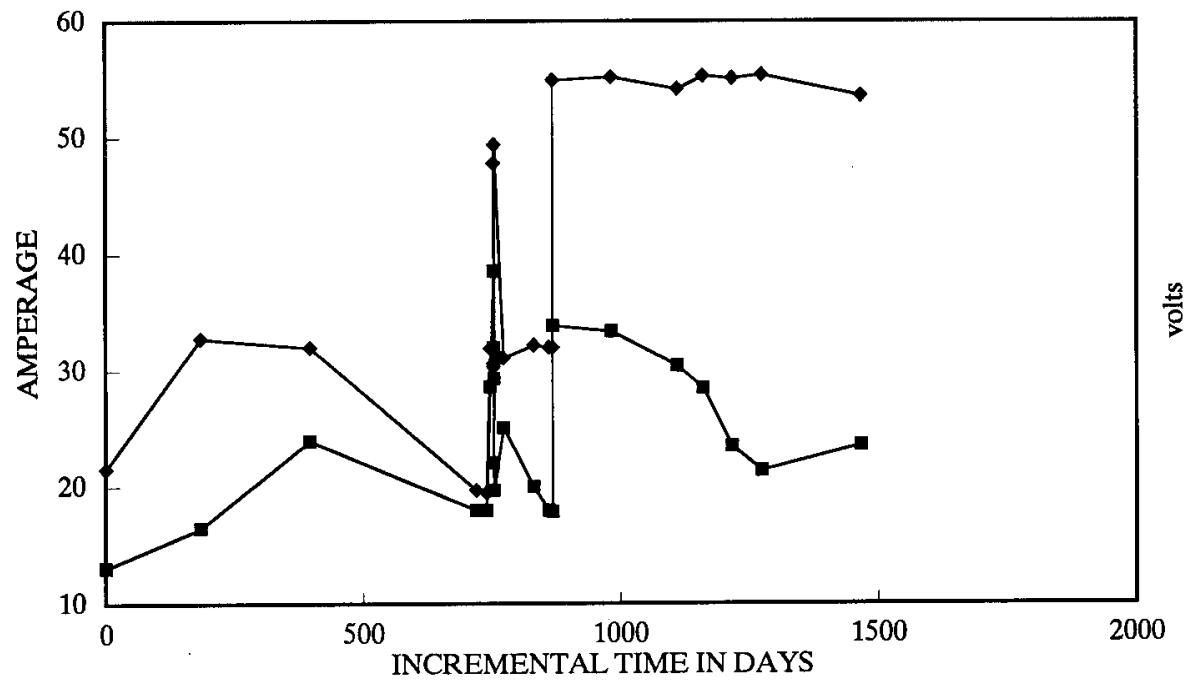

$\rightarrow$ AMPS $\rightarrow$ VOLTS

PERF-\#R1 - NAMEPLATE 100 VOLTS / 60 AMPS

BASELINE DATE - 7/94; RESURVEY DATE - 1/95 